\title{
BEHAVIOUR OF NOVEL STIFFENED ANGLE SHEAR CONNECTORS AT AMBIENT AND ELEVATED TEMPERATURES
}

\author{
Karim Nouri ${ }^{1, *}, \mathrm{~N}$ H Ramli Sulong ${ }^{1,2}$, Zainah Ibrahim ${ }^{1, *}$ and Mahdi Shariati ${ }^{1}$ \\ ${ }^{1}$ Department of Civil Engineering, Faculty of Engineering, University of Malaya, 50603 Kuala Lumpur, W.Persekutuan Kuala Lumpur, Malaysia \\ ${ }^{2}$ School of Civil \& Environmental Enginnering, Science \& Engineering Faculty, Queensland University of Techenology, 2 George St, Brisbane QLD 4000, Australia \\ *(Corresponding authors: E-mail: k.nouri@siswa.um.edu.my; zainah@um.edu.my)
}

\section{A B S T RA C T}

This paper presents experimental studies to investigate the behaviour of stiffened angle shear connectors subjected to isothermal fire loading. Push-out tests were conducted on 48 specimens covering various geometries of stiffened angle shear. The specimens were initially heated at room temperature, which gradually increased to target temperatures, and loaded up to failure for the assessment of their shear resistance at high temperatures. The behaviour of these connectors at ambient and high temperatures was compared. Results showed that the full-length stiffened angle shear connectors exhibited higher shear resistance compared with the half-length ones, whereas the ductility of the half-length stiffened shear connectors was greater than that of the full-length ones; the connector fracture governed the failure mode. Although heating exerted a substantially destructive effect on the resistance of the shear connectors, it led to increased ductile behaviour.

Copyright $(\odot 2021$ by The Hong Kong Institute of Steel Construction. All rights reserved.

\section{Introduction}

Composite structures employing normal-weight concrete have been used in bridge construction for more than half a century, with the related literature dating back to the 1920 s [1-3]. In recent decades, the main progress in composite structures has been due to the outcome of the basic design provisions nominated by the American Institute of Steel Construction in 1961 [4]. Shear connectors between concrete slabs and steel beams in composite construction play a significant role in the seismic response of a structure [5]. They provide the essential shear connection for composite action in flexure, which is used to distribute the large horizontal inertial forces in a slab to the main lateral loadresisting elements of the structure. During an earthquake, such shear connectors are adjusted to reverse cyclic loading [6].

Headed studs, perfobond ribs, channels and wires are known as the most common shear connectors. Recently, the demand for innovative shear connectors has led to other forms of connection by using steel angles, coldformed shapes and powder-actuated attachments. In developing countries, stud connectors are minimally utilised in the industry due to not only the lack of skill labour but also the cost of manufacturing. Although the most common shear connector is headed stud, perfobond ribs, channels and angle shear connectors are also widely adopted due to ease of installation, availability and higher loadcarrying capacity. In addition, angle and channel shear connectors do not require inspection rules that are used for stud connectors, such as the bending test. During the installation of transverse slab reinforcement, shear connectors are less problematic than perfobond connectors. Hence, angle and channel shear connectors are amongst the most preferred choices to overcome the drawbacks of headed studs and perfobond shear connectors in composite beams. Angle profile can be used in L- and C-shaped angle connectors. Between these two, $\mathrm{C}$-shaped angle shear connectors have better performance and high shear resistance [7-14].

A composite structure requires the consideration of the design process under risk conditions, given that the behaviour of a composite structural system under fire is outstandingly different from its behaviour at ambient temperatures. The investigations on the Broadgate fire and the Cardington structure [15] have improved the conception of structural interactions and load distribution occurring in a real building under fire. The structures are typical examples of the current UK steel construction with concrete-profiled deck floor slabs performing compositely with hot-rolled steel beams mostly left unprotected. Although tests have indicated that high temperatures might be sustained, the results are inadequate and do not explain the mechanics governing the structures' response to fire. The interactions amongst thermal expansion, large deformation effects, material degradation and 3D effects on a building have complicated the understanding of the behaviour of composite members through the development and investigation of high-quality numerical and analytical models. Few studies have focused on the behaviour of isolated members in composite structures.
A R T I C LE H I S T ORY

$\begin{array}{ll}\text { Received: } & 16 \text { February } 2020 \\ \text { Revised: } & 15 \text { October } 2020 \\ \text { Accepted: } & 26 \text { October } 2020\end{array}$

\section{K E Y W O R D S}

Stiffened Shear Connector; Composite;

Angle;

Monotonic Loading,

Elevated Temperature;

Ambient Temperature
Sanad et al. [16] studied the structural action in a two-way slab and composite beam structure subjected to compartment fire, showing that 1) the performance of indeterminate structures under fire was governed by thermal expansion and 2) local yielding and large deflections reduced the damage to the overall structure. Mäkeläinen and Ma [17] studied the thermal and structural performance of a slim floor beam under fire through a numerical analysis by applying ISO standard fire and natural fire. The results showed that an increment in temperature significantly influenced the flexural capacity of the beam, which depended on the shear connection to maintain performance. In the last study performed by Mirza and Uy [18], FEM and experimental tests were conducted to analyse the effects of raised temperatures on the behaviour of composite steel-concrete beams for solid and profiled steel sheeting slabs. In the current study, material properties varied with temperature; hence, the behaviour of reinforced concrete slabs under fire conditions highly depended on the interaction of the surrounding elements. In the following, steel sheet slabs exhibited great fire resistance compared with ambient temperature strength [18].

Rodrigues and Laím [19, 20] conducted a comprehensive experimental study on T, T-block, T-perfobond and perfobond shear connectors at different temperatures to assess the structural behaviour of the shear connectors under fire. From the current study, elevated temperatures adversely influenced the connector load-carrying capacity, in which T-perfobond connectors exhibited the worst behaviour, whereas $\mathrm{T}$ connectors showed the best one. The perfobond connections obtained from the two connectors indicated the worst behaviour in the fire, whereas the connector with one hole and without any steel reinforcement passing through it showed the best behaviour. A study conducted with partial composite beams with flat lightweight concrete slabs showed an overall reduction in the composite beam load-carrying capacity due to being heated at elevated temperatures and post-fire ambient conditions. The composite beams and connections sustained the loading and heating up to $700{ }^{\circ} \mathrm{C}$ on the service level. However, the shear tab connection fractured during cooling, which highlighted the significance of the heating and cooling phases of a fire [21]. To improve the performance of L-shaped angle shear connectors, stiffened angle shear connectors were proposed. The stiffener was prefabricated, and its welding procedure was as simple as the welding of angle shear connectors (which requires nonspecific equipment); accordingly, the advantages of $\mathrm{C}$-shaped angle shear connectors could remain for stiffened angle shear connectors. This research focused on the behaviour assessment of the stiffened angle shear connectors at ambient and elevated temperatures with isothermal condition. The three elevated temperature levels of isothermal heating were $550{ }^{\circ} \mathrm{C}, 700{ }^{\circ} \mathrm{C}$ and $850{ }^{\circ} \mathrm{C}$. The shear connector behaviour in terms of failure mode, ductility, load-carrying capacity, strength at ambient temperatures, the effect of temperature on the mentioned parameters and the heat distribution at different temperature elevations was examined. 


\section{Test programme}

\subsection{Test plan}

Forty-eight push-out tests were conducted and divided into two series. Each series used two types of angle section with heights of 100 and $75 \mathrm{~mm}$ and three different lengths of 30,50 and $80 \mathrm{~mm}$ as shear connectors. Then, each type was divided into two groups on the basis of its stiffener height, i.e. full- and halflength stiffener. As reflected in the name, full-length stiffened means that the stiffener has a height equal to the shear connector's height. On the contrary, half-length stiffened means that the height of the stiffener is half of the height of the shear connector. Four specimens were considered for each group under monotonic loading at ambient temperatures, $550{ }^{\circ} \mathrm{C}, 700{ }^{\circ} \mathrm{C}$ and $850{ }^{\circ} \mathrm{C}$. The specimens were labelled for the identification of their individual behaviour. The specimens' ID and the geometric properties of the angle shear connectors are presented in Table 1. In the symbolisation of the specimens in the table, the first letter indicates the type of shear connector, which is angle shear connector; the next two or three digits represent the height; the next two digits represent the length; the second letter is the height of the stiffener, and the last digits define the temperature.

\subsection{Specimens}

Push-out specimens comprised a steel I-section (IPE270) beam with two reinforced concrete slabs attached to each flange of the beam. The stiffened shear connector was attached to each beam flange by welding, and $10 \mathrm{~mm}$ diameter steel bar hoops were used at the top and bottom of the slab to reinforce the concrete. Details of the push-out specimens are in accordance with the recent studies on the behaviour of $\mathrm{C}$-shaped angle and channel shear connectors under different conditions [8, 12, 14, 22-27]. To design a stiffener, a triangle-shaped truss was considered and was expected to have a vital role in increasing the ultimate load capacity of the shear connector. Hence, this concept can reduce the number of shear connectors in a structure, which not only assists in saving steel and installation time but also leads to cost savings. The implication of this design is that the triangle-shaped stiffener increases the strength and stiffness of the connector in transferring the load to the beam. The strength enhancement has significant role and effect at elevated temperature when the mechanical strength of steel drops dramatically. The schematic of the test specimens is shown in Fig. 1. The properties of steel components in this study were tested in accordance with coupon tensile test ASTM 370 (ASTM 2005) [28]; the material properties of the steel components are provided in Table 2.

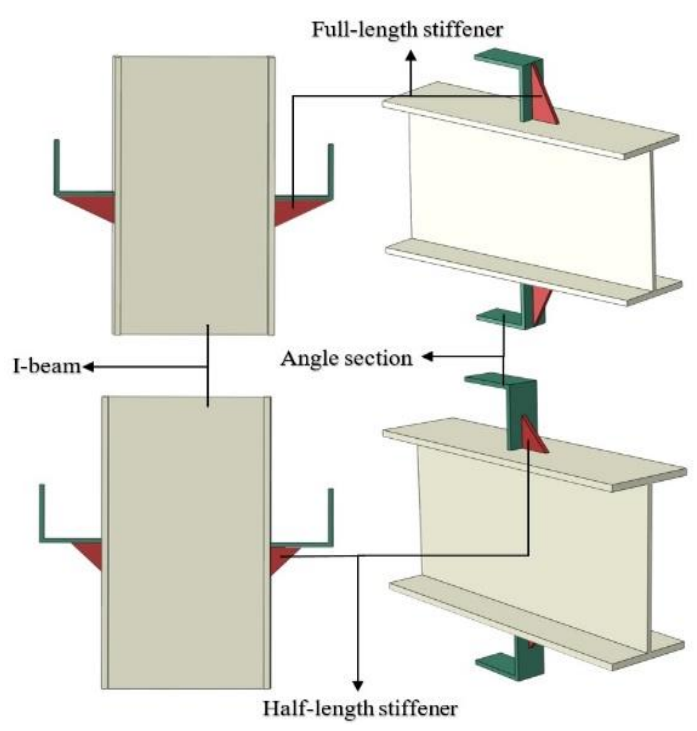

Fig. 1 Details of test specimens

Table 1

Specimen IDs and geometrical properties of angle shear connectors

\begin{tabular}{cccccc}
\hline NO & ID & $\begin{array}{c}\text { Height } \\
(\mathrm{mm})\end{array}$ & $\begin{array}{c}\text { Length } \\
(\mathrm{mm})\end{array}$ & Stiffener & Temperature $\left({ }^{\circ} \mathrm{C}\right)$ \\
\hline 1 & A-100-80-F-A & 100 & 80 & F - 100 & 25 \\
2 & A-100-80-F-550 & 100 & 80 & F - 100 & 550 \\
3 & A-100-80-F-700 & 100 & 80 & F - 100 & 700
\end{tabular}

8

A-100-80-H-A

A-100-80-H-550

A-100-80-H-700

A-100-80-H-850

A-100-50-F-A

A-100-50-F-550

A-100-50-F-700

A-100-50-F-850

A-100-50-H-A

A-100-50-H-550

A-100-50-H-700

A-100-50-H-850

A-100-30-F-A

A-100-30-F-550

A-100-30-F-700

A-100-30-F-850

A-100-30-H-A

A-100-30-H-550

A-100-30-H-700

A-100-30-H-850

A-75-80-F-A

A-75-80-F-550

A-75-80-F-700

A-75-80-F-850

A-75-80-H-A

A-75-80-H-550

A-75-80-H-700

A-75-80-H-850

A-75-50-F-A

A-75-50-F-550

100

80

F - 100

850

100

100

100

80

H - 50

H - 50

H - 50

H - 50

F - 100

F - 100

F - 100

F - 100

H - 50

H - 50

H - 50

H - 50

F - 100

F - 100

F - 100

F - 100

H - 50

H - 50

H - 50

H - 50

F - 100

F - 100

F - 100

F - 100

H - 50

H - 50

H - 50

H - 50

F - 100

F - 100

F - 100

F - 100

A-75-50-F-850

A-75-50-H-A

A-75-50-H-550

H - 50

H - 50

$\mathrm{H}-50$

H - 50

F - 100

F - 100

F - 100

F - 100

H - 50

H -50

H - 50

H - 50

Table 2

Coupon tensile test result

\begin{tabular}{cccc}
\hline Specimens & 1 & 2 & 3 \\
\hline Fy (MPa) & 338.8 & 341.85 & 340 \\
Fu (MPa) & 493.86 & 495.03 & 495.77 \\
Elongation (\%) & 24.23 & 23.74 & 24.16 \\
Fy Average (MPa) & & 340.22 & \\
\hline
\end{tabular}




\begin{tabular}{cc}
\hline Fu Average (MPa) & 494.89 \\
Elongation Average (\%) & 24.04 \\
$F_{u} / F_{y}$ & 1.45 \\
\hline
\end{tabular}

\subsection{Concrete materials and mix proportions}

Air-dry condition aggregates were used in the concrete mixes, in which the fine aggregate was graded silica sand with a maximum nominal size of $4.75 \mathrm{~mm}$, and the coarse aggregate was crushed granite with a maximum nominal size of $10 \mathrm{~mm}[29,30]$. The cement used in all mixes was ordinary Portland cement corresponding to ASTM C150 (cement) type II [31-33]. To attain acceptable workability, a superplasticiser (SP; Rheobuild 1100) was used in the concrete mixes (Table 3). Superplasticizer (SP) (dark brown and $\mathrm{pH}$ of 6.0-9.0) has a specific gravity of approximately 1.195 [34]. Short, angle lengths were used due to the concrete slab size limitation. All push-out specimens were cast in a horizontal position similar to site situations, whilst a qualified reliable concrete for both sides of the specimen slabs was assumed (Fig. 2). To measure the compressive strengths, standard cylinders with $150 \mathrm{~mm}$ diameter and $300 \mathrm{~mm}$ length and standard cubes with $100 \mathrm{~mm}$ length were cast with the push-out specimens simultaneously. All the specimens, cylinders and cubes were cured in water for 28 days before testing (Fig. 3a). The concrete strength was measured during the cylinder and cube compression tests. The requirements of ASTM C39 (ASTM 2005) [35] were adopted for the compressive strength test procedure, and the mean of the concrete compression strength was calculated. The average strength of concrete compression was $50 \mathrm{MPa}$ (Fig. 3b).

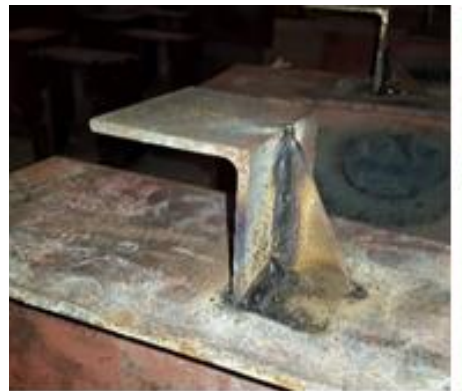

(a) beams with welded connectors

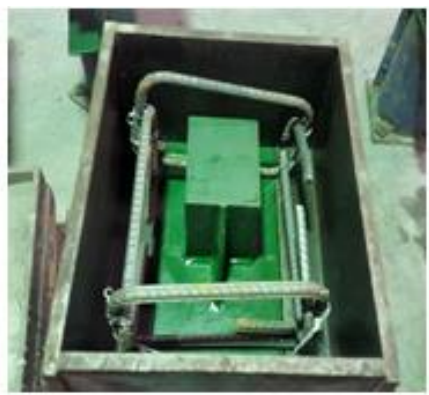

(b) molding and rebar placement

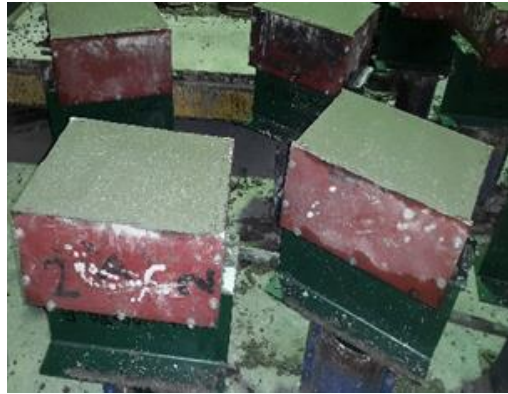

(c) poured concrete

Fig. 2 Fabrication and preparation of push-out specimens

Table 3

Mix proportions of concrete materials by weight

\begin{tabular}{|c|c|c|c|c|c|c|c|c|c|}
\hline 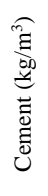 & 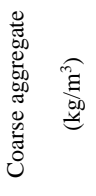 & 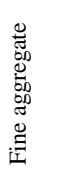 & 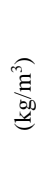 & 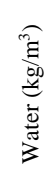 & 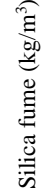 & $\begin{array}{l}\frac{\partial}{2} \\
\stackrel{2}{\infty}\end{array}$ & $\frac{U}{3}$ & 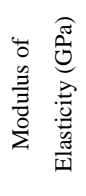 & 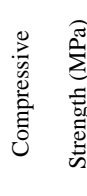 \\
\hline 460 & 910 & 825 & & 168 & 40 & 0.5 & 0.37 & 39 & 35 \\
\hline
\end{tabular}

\subsection{Loading and test procedure}

The specimens were initially heated at room temperature and increased to a target temperature, then they were loaded up to failure. The loading condition was based on isothermal heating conditions. Each series of specimens was tested under monotonic loading at temperatures of $25^{\circ} \mathrm{C}, 550{ }^{\circ} \mathrm{C}, 700{ }^{\circ} \mathrm{C}$ and $850{ }^{\circ} \mathrm{C}$. The desired temperatures were obtained using flexible ceramic pad (FCP) heating elements (Fig. 4a) that used a high-voltage electrical transformer
(Fig. 4b) for FCP heating through a high-resistance wire. This method was used in previous research by Haremza et al. [36]. The sample in the heated zone was thermally insulated with Rockwool (Fig. 5), which had a density of $128 \mathrm{~kg} / \mathrm{m} 3$ to avoid losing heat during the test. The temperature was recorded using a calibrated temperature recorder (Fig. 4c) for the flange temperature. Two type$\mathrm{K}$ thermocouple cables (Fig. 6) were installed in the middle and top of the shear connector and connected to the data logger to observe heat expansion through the shear connector embedded in the reinforced concrete.

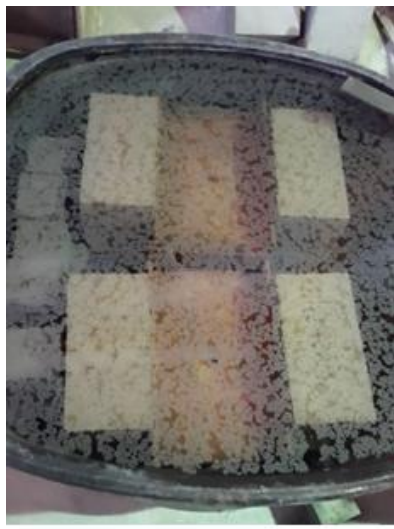

Fig. 3a Curing all specimens

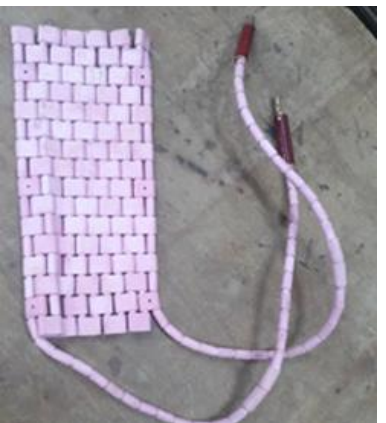

(a) Flexible Ceramic Pad (FCP)

elements

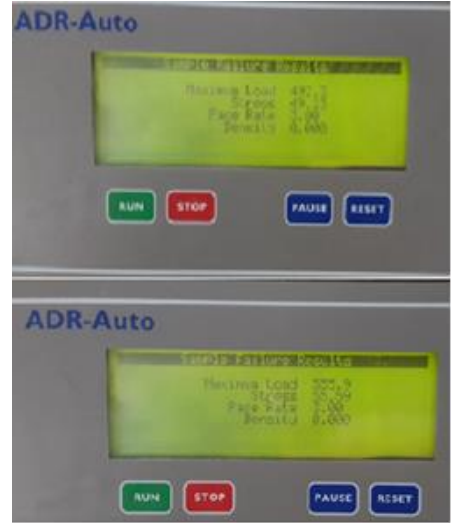

Fig. 3b Compression test results

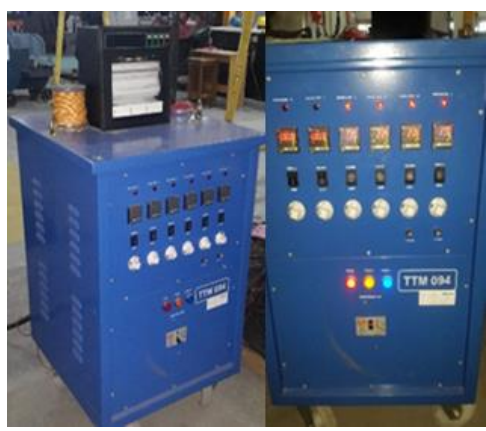

(b) Electrical transformer for heating heating the CFPs

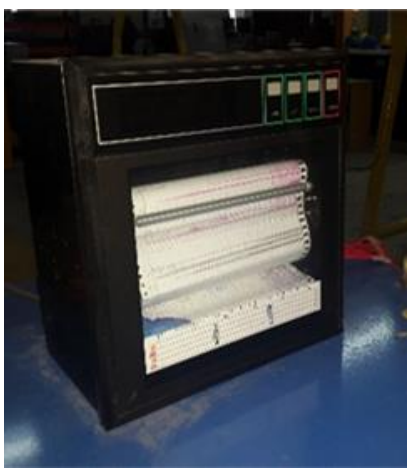

(c) Calibrated temperature recorder

Fig. 4 Equipment for the fire test

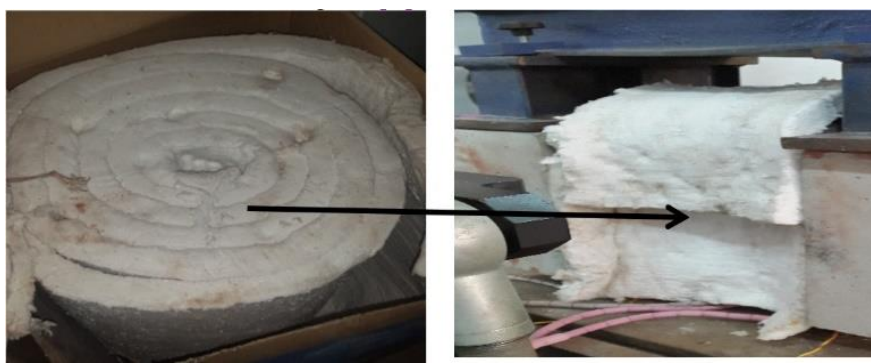

Fig. 5 Rock-wool for specimen isolation 


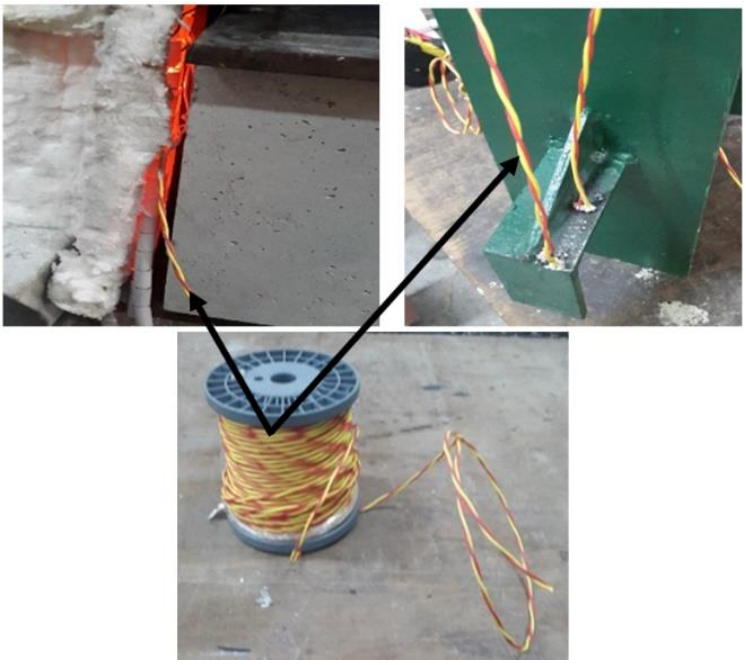

Fig. 6 Type-K thermocouple cables used for measuring the temperature in specimens

A universal testing machine with $600 \mathrm{kN}$ capacity was used to apply a monotonic load. Fig. 7 shows the push-out test setup. Displacement control was used at a rate of $0.04 \mathrm{~mm} / \mathrm{s}$ for the monotonic loading [13,37]. The practical load and relative slip between the I-beam and the concrete slab were automatically recorded at each time step by using the universal machine. The universal testing machine was able to plot a loading versus displacement graph. The behaviour of the stiffened shear connectors could be assessed on the basis of raw data and graph.
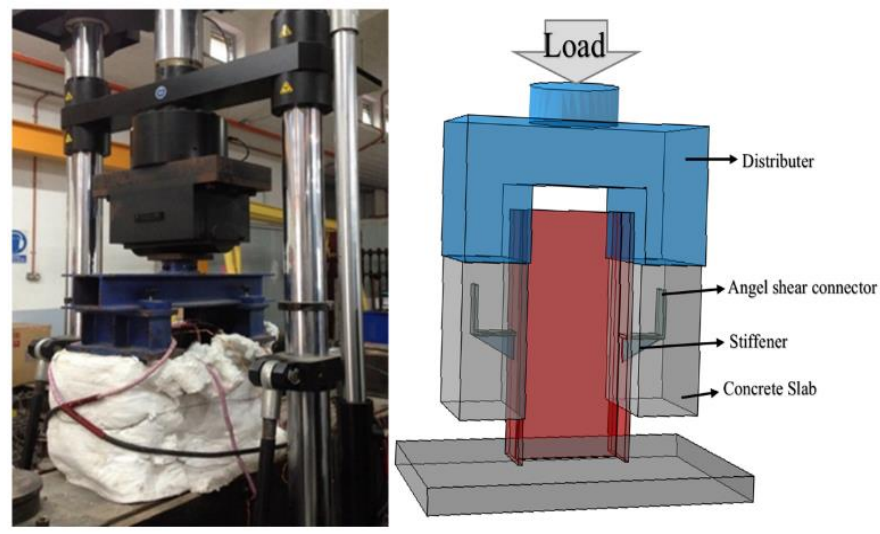

Fig. 7 Typical test setup for specimens at elevated temperatures

Regarding the steel I-beams, on the basis of the universal test machine deck, a change in the angle connector orientation resulted in a variation in the ultimate strength of the connectors and relative stiffness $[12,38]$ accepted in all pushout tests (Fig. 7). When the push-out sample temperature was constant, the ultimate load capacity gained from the tests at room temperature was followed by heating up of the specimens to target temperature at the same heating rate based on the ISO 834 fire curve [39].

\section{Results and discussion}

\subsection{Heat distribution}

The stiffened angle shear connectors were tested at different temperatures. The temperature of a stiffened angle shear connector was monitored using a type-K thermocouple, which was connected to the I-beam and the top and middle of the shear connector, as shown in Fig. 8. The propagation of heating through the I-beam and shear connector was measured. As indicated in Fig. 9a$\mathrm{c}$, the heat distribution through the specimens followed the same pattern due to the heat transfer coefficient of concrete and steel. The temperature distribution at three different locations is summarised in Table 4 . For the tests at $550{ }^{\circ} \mathrm{C}$ and $700{ }^{\circ} \mathrm{C}$, the percentage of temperature reduction in the middle and top of a shear connector compared with the flange temperature was within the similar ranges of $53 \%-54 \%$ and $73 \%-75 \%$, respectively. The temperature reduction for the same locations in the $850{ }^{\circ} \mathrm{C}$ test was much lower, i.e. $42 \%$ and $58 \%$, respectively. All temperature reductions from the I-beam to the shear connector strongly depended on the thermal conductivity of the steel and concrete and the time of heat application to reach the target temperature.

This result showed that the temperature at the flange was higher at the top of the shear connector, which was caused by the transfer of heat to the concrete. The concrete attracted heat from the flange and shear connector; therefore, the area that surrounded the shear connector received substantial heat which had a destructive effect on the concrete's properties. The strength of concrete drops in the area where the concrete stresses are high, which leads to concrete crushing and propagation of cracks. The strength properties of steel and concrete at elevated temperature decrease with time. Accordingly, if the structure is on fire, the strength and stability of the structure diminish tremendously over time. The average temperature of the shear connector increased by $50 \%$ from $700{ }^{\circ} \mathrm{C}$ to $850{ }^{\circ} \mathrm{C}$, which indicated an extensive damaging effect on its behaviour and proved that, at elevated temperature, a stiffer design is required to address the drawback that the designed stiffener can assist and sustain the shear connector significantly. Thus, the flange of the I-beam at the bottom of the stiffened shear connector had the highest temperature-induced destructive effect on the mechanical properties of steel, leading to the fracture of the shear connector in this area.

Table 4

Heat distribution in the I-beam and shear connector

\begin{tabular}{|c|c|c|c|c|c|c|c|}
\hline Location & 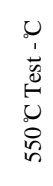 & 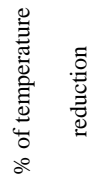 & 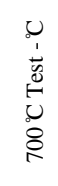 & 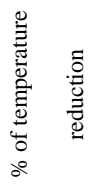 & $\begin{array}{l}u \\
1 \\
1 \\
0 \\
0 \\
0 \\
0 \\
\infty \\
\infty\end{array}$ & 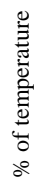 & 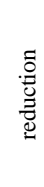 \\
\hline Flange of I beam & 551 & - & 701 & - & 855 & - & \\
\hline Middle of shear connector & 260 & $53 \%$ & 325 & $54 \%$ & 493 & $42 \%$ & \\
\hline Top of shear connector & 157 & $72 \%$ & 175 & $75 \%$ & 355 & $58 \%$ & \\
\hline
\end{tabular}

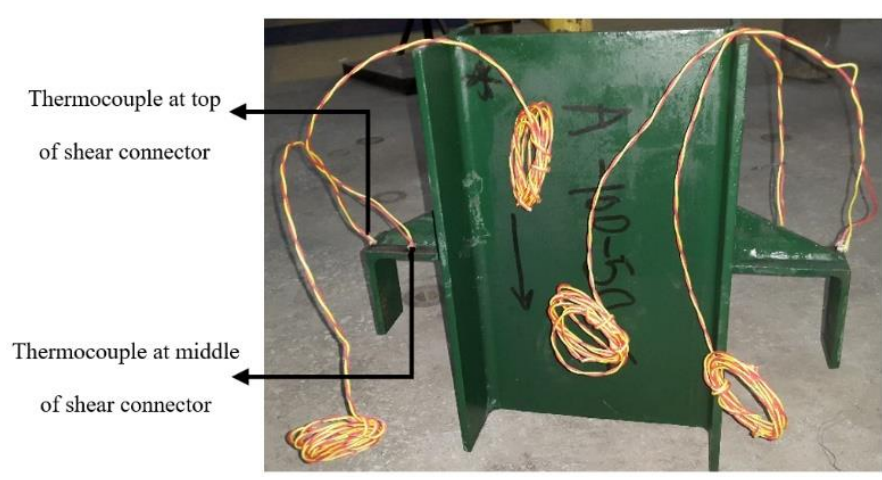

Fig. 8 Type-K thermocouple connected to the middle and top of the connector

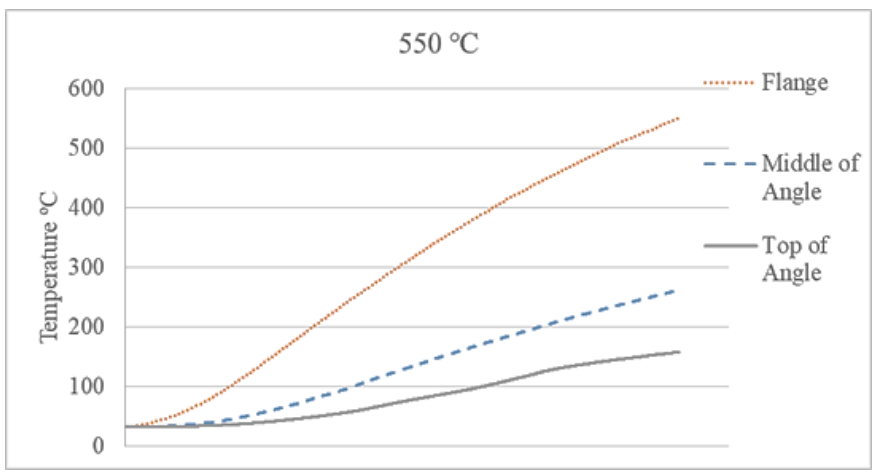

(a) Propagation of heat through at $550^{\circ} \mathrm{C}$ 


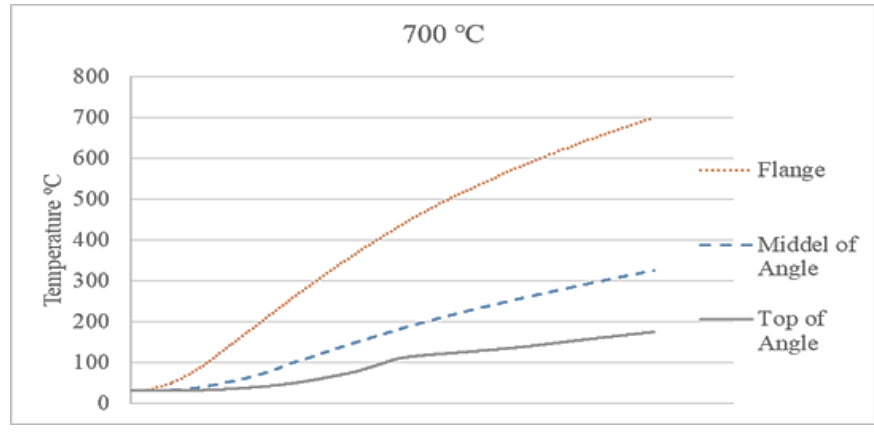

(b) Propagation of heat through at $700^{\circ} \mathrm{C}$

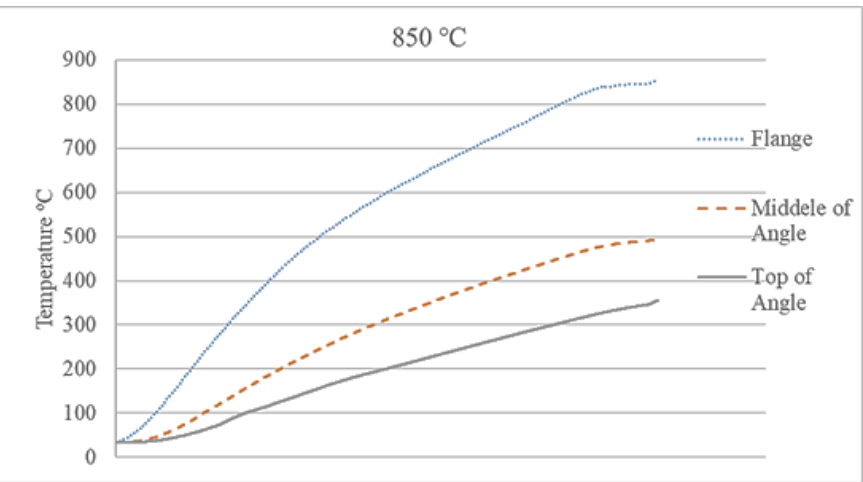

(c) Propagation of heat through at $850^{\circ} \mathrm{C}$

Fig. 9 Propagation of heat through the I-beam and shear connector

\subsection{Failure type}

The push-out specimens indicated two types of failure: connector fracture and concrete crushing splitting. The former was found in most of the specimens at room and elevated temperatures (Fig. 10), in which it occurred from the upper welding line. Although most specimens failed with the same type of failure at ambient and elevated temperatures, the failure at ambient temperatures was less ductile than that at elevated temperatures, which was caused by the stiffener that made the shear connectors stiff at ambient temperatures. At elevated temperatures, the shear connectors behaved more ductile due to the reduction in steel strength. Concrete crushing occurred around the connectors for the stiffened shear connectors with $80 \mathrm{~mm}$ width at room temperature. In fact, the width of the $\mathrm{C}$-shaped shear connector plays a vital role in terms of its strength. Therefore, the connector area facing the force is enhanced by increasing the width of the angle profile, which leads to concrete crushing at ambient and elevated temperatures.

The potential damage to strength caused by heating must be considered. The heating included the vaporisation of free water at approximately $100{ }^{\circ} \mathrm{C}$, which meant that humidity had no effect on the concrete strength during the test; the dissociation of $\mathrm{Ca}(\mathrm{OH})_{2}$ into $\mathrm{CaO}$ and $\mathrm{H}_{2} \mathrm{O}$ between $400{ }^{\circ} \mathrm{C}$ and $500{ }^{\circ} \mathrm{C}$; and the quartz transformation of some aggregates above $600^{\circ} \mathrm{C}$; the concrete started sweating and cracking at approximately $450^{\circ} \mathrm{C}$ [40]. The failure mode observed under monotonic loading at elevated temperatures for the stiffened angle shear connectors was accompanied by a longitudinal crack throughout the slab.

The observed cracks were due to concrete and steel isotropic essence. The thermal increase of the concrete depended on temperature alteration. Some cracks formed around the surface of the connectors and in a direction parallel to the steel I-beam. As Bazant and Kaplan [41] observed, cracking occurs due to structural stresses in concrete caused by inhomogeneous thermal increases, which are expressed as a temperature function on the basis of Eurocode 2 [42]. Figs. 11 and 12 show the mentioned phenomenon during and after the hightemperature experiments, respectively.
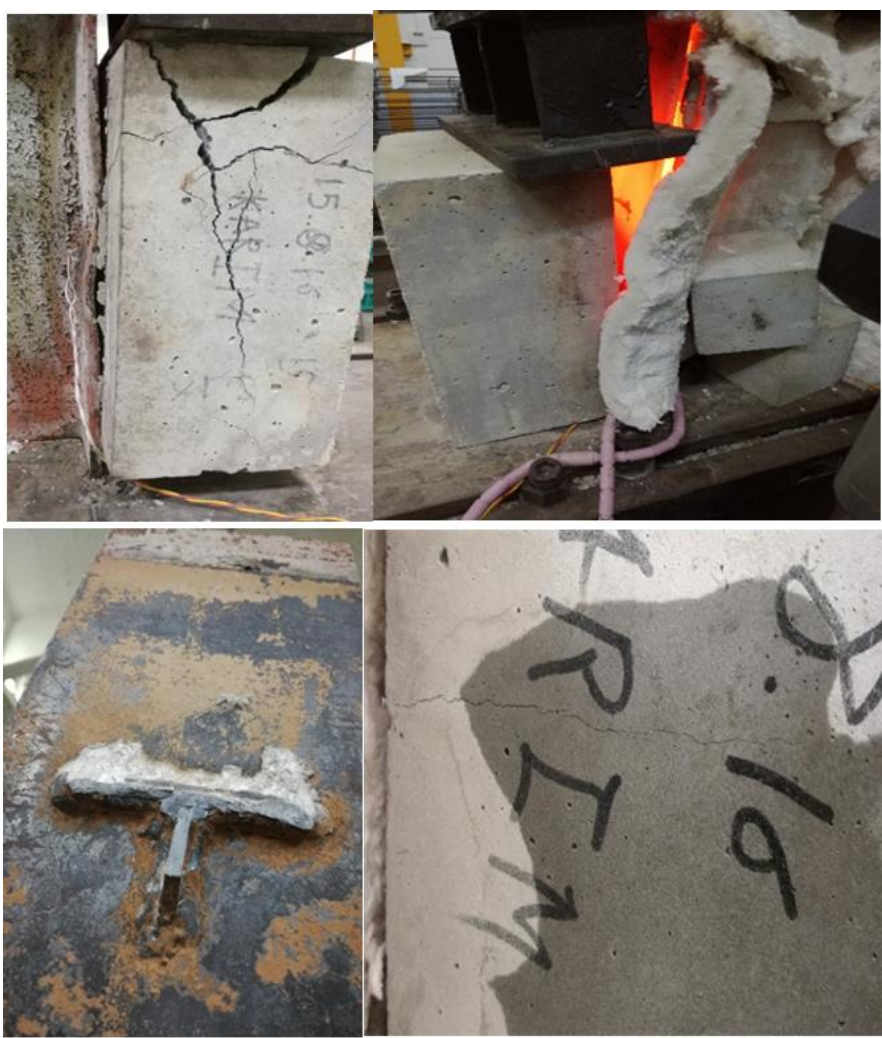

Fig. 10 Typical failure of a stiffened angle shear connector specimen

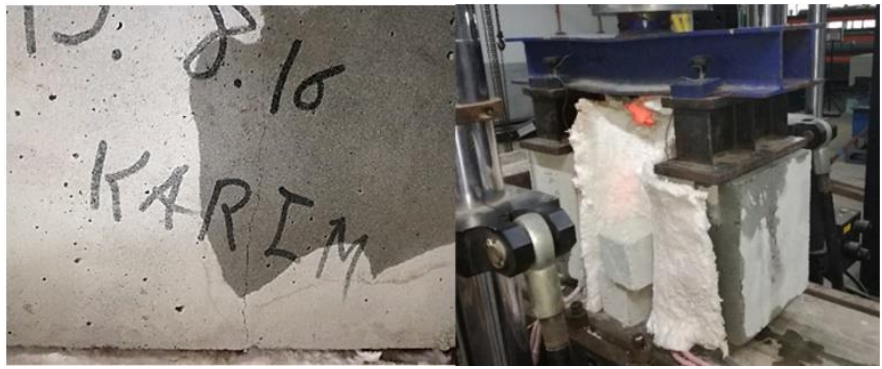

Fig. 11 Cracks on concrete slab during connector specimen failure at ambient and elevated temperatures

\subsection{Load-slip analysis}

Tables 5 and 6 show the highest capacity of shear and slip load gained from the test specimens by referring to the load-slip curve for the monotonic load of all the push-out experiment specimens at all temperatures, as shown in Fig. 13a1. The load-slip curves were plotted using a universal testing machine with 600 $\mathrm{kN}$ capacity. The universal testing machine recorded load versus displacement every second. In addition, a distributer was used to apply load on both concrete slabs. The distributer was made using 2 UC $100 \times 100 \times 17.20 \mathrm{~kg}$; hence, the deflection of the distributer during the test under $600 \mathrm{kN}$ was $0.018 \mathrm{~mm}$, which was neglected in the analysis. Shear resistance data and the highest slip related to the push-out experiments for all samples are also shown in Tables 5 and 6 .

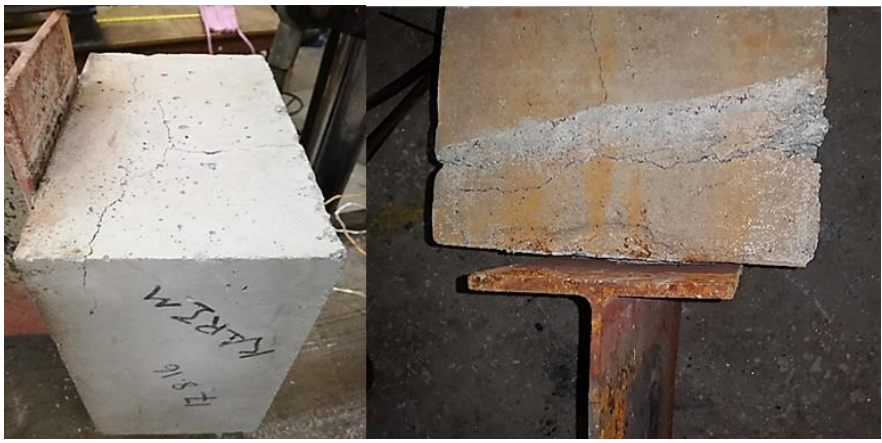

Fig. 12 Cracks on concrete slab after connector specimen failure at elevated temperature 
Karim Nouri et al.

33

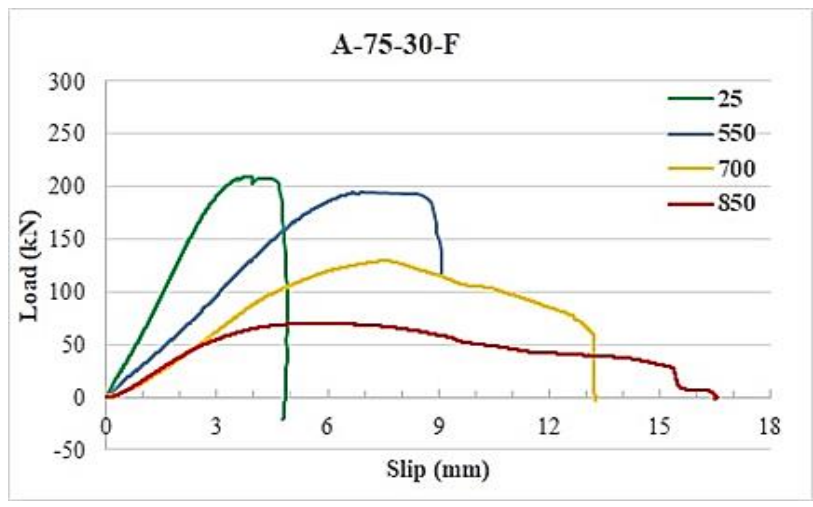

(a) A-75-30-F

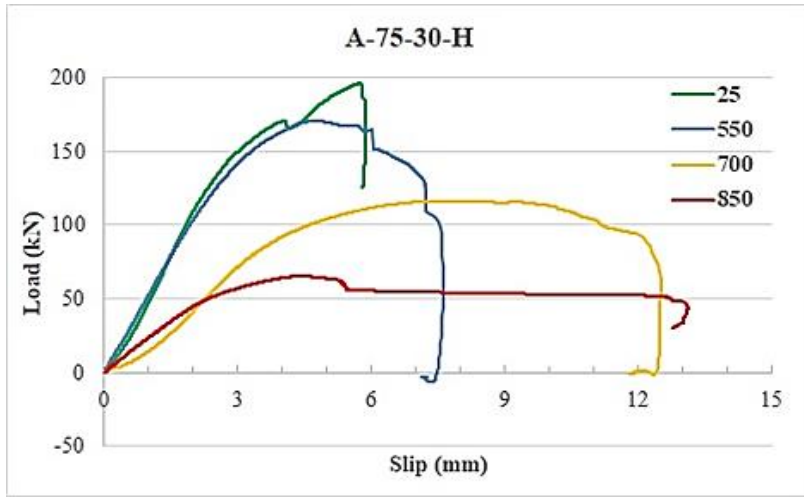

(b) A-75-30-H

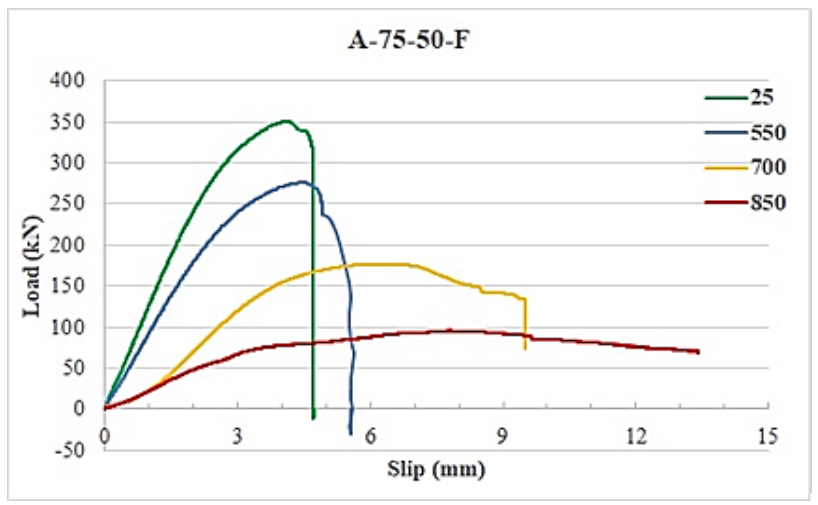

(c) A-75-50-F

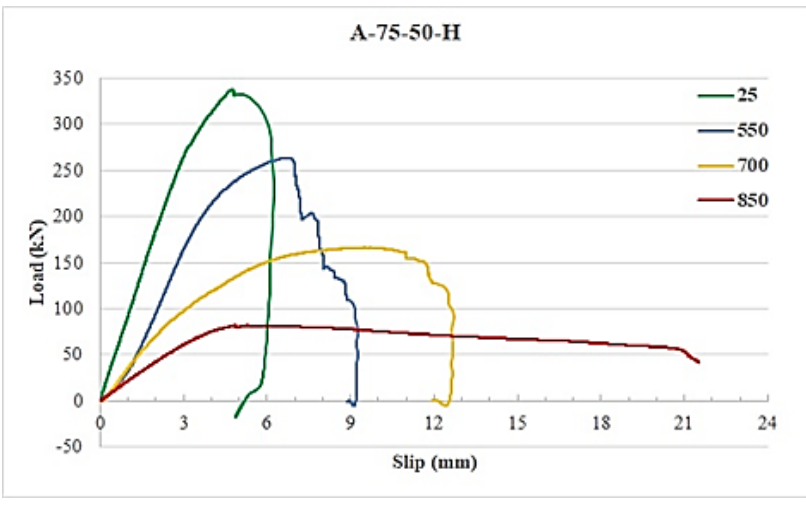

(d) A-75-50-H

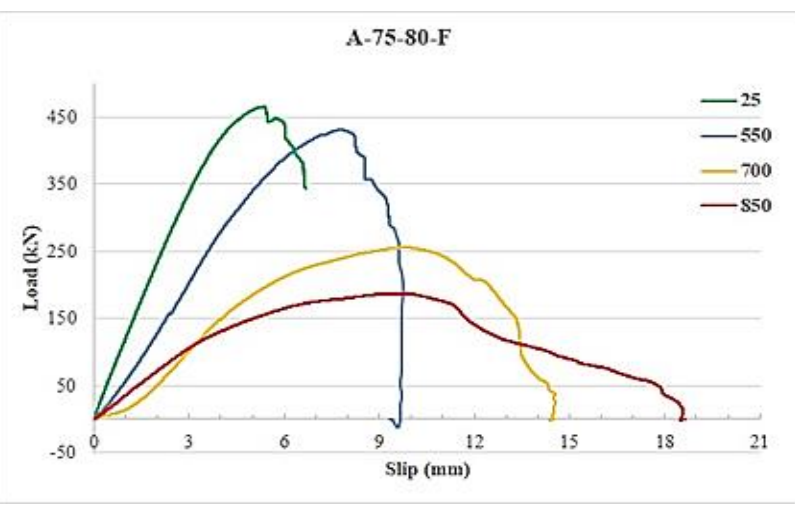

(e) A-75-80-F

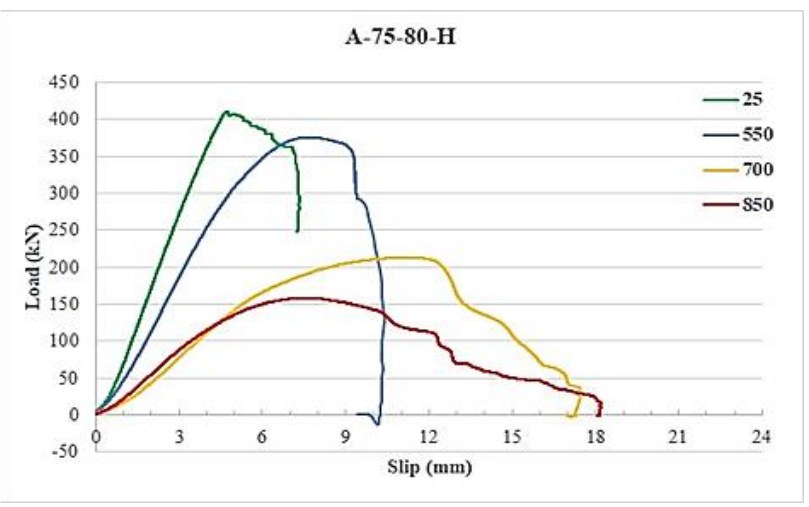

(f) A-75-80-H

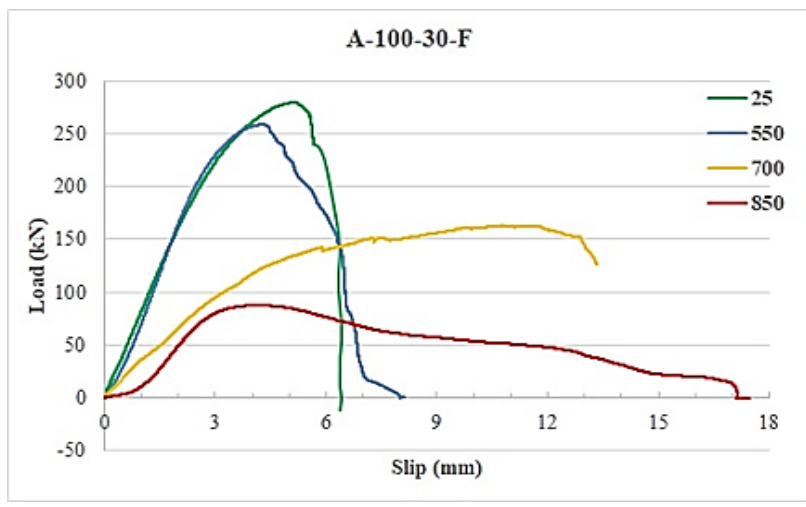

(g) A-100-30-F

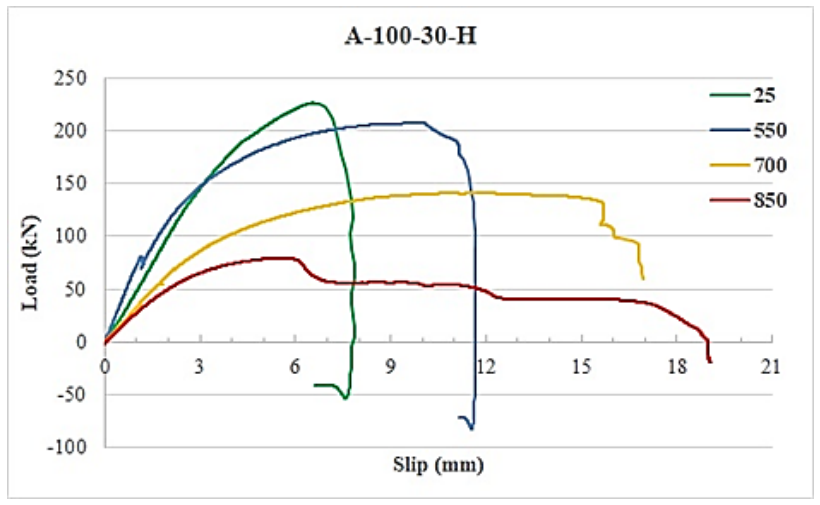

(h) A-100-30-H 


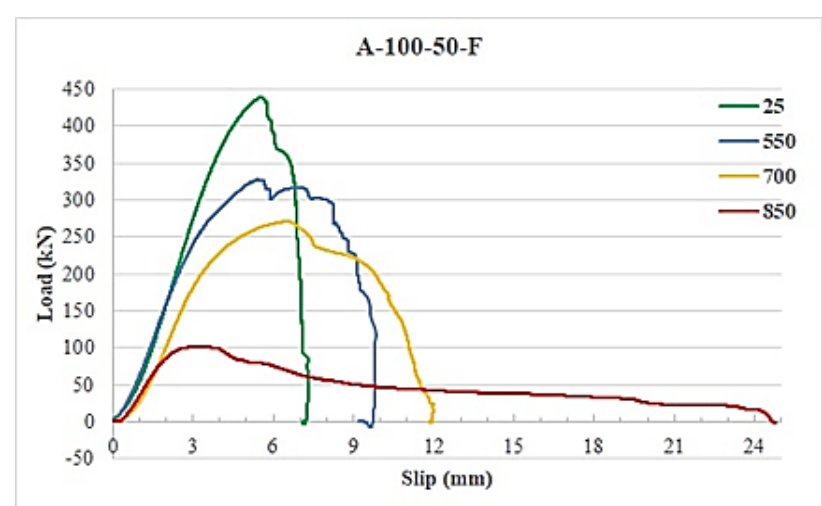

(i) A-100-50-F

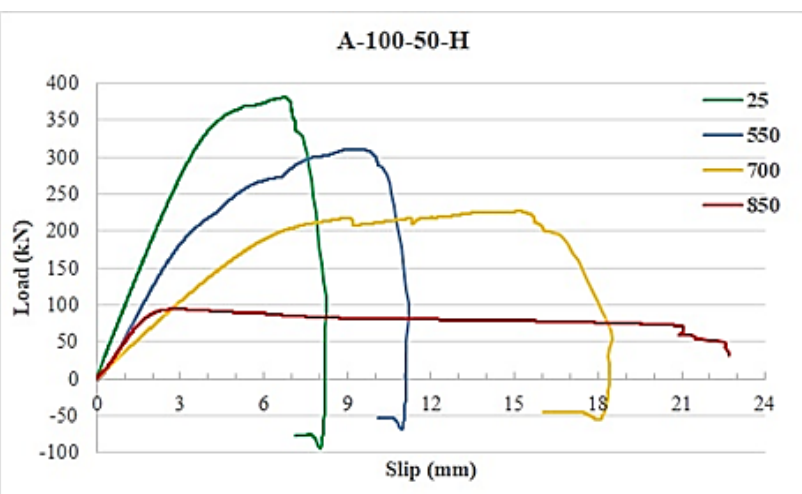

(j) A-100-50-H

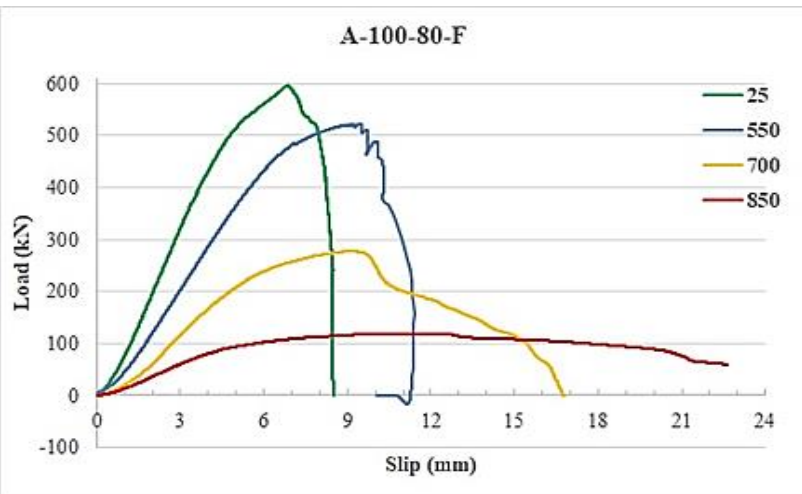

(k) A-100-80-F

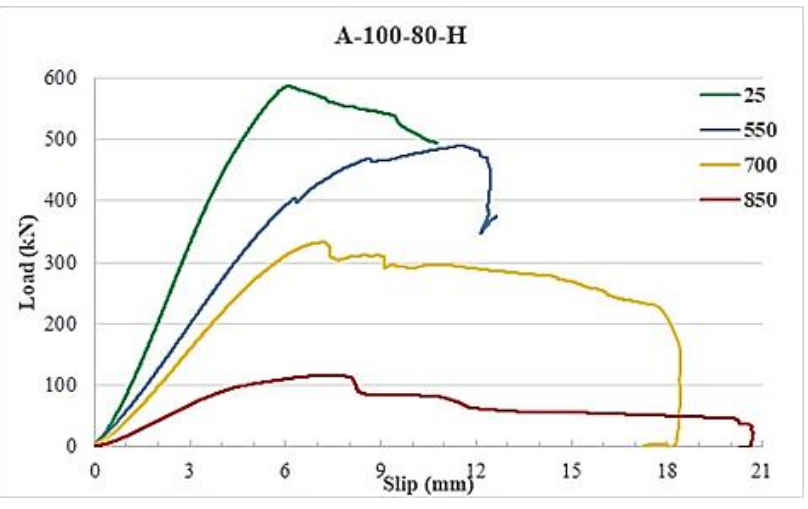

(1) A-100-80-H

Fig. 13 Load-slip curve for monotonic load at different temperatures
Table 5

Summary of failure loads and slips for all tested angle shear connector specimens in Group 1

\begin{tabular}{|c|c|c|c|c|c|c|}
\hline Specimen ID & 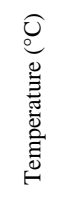 & 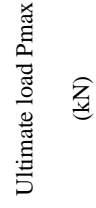 & 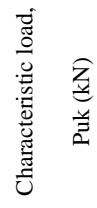 & 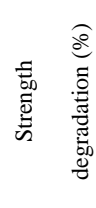 & 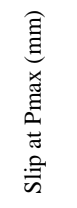 & 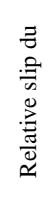 \\
\hline A-75-30-F & 25 & 209.75 & 188.77 & - & 4.91 & 2.93 \\
\hline A-75-30-F & 550 & 195.44 & 175.90 & 6.82 & 9.10 & 5.48 \\
\hline A-75-30-F & 700 & 129.55 & 116.60 & 38.23 & 13.28 & 5.74 \\
\hline A-75-30-F & 850 & 70.12 & 63.11 & 66.57 & 16.57 & 3.73 \\
\hline A-75-30-H & 25 & 195.90 & 176.31 & - & 5.88 & 4.65 \\
\hline A-75-30-H & 550 & 170.93 & 153.84 & 12.75 & 7.62 & 3.46 \\
\hline A-75-30-H & 700 & 116.22 & 104.60 & 40.67 & 12.51 & 5.05 \\
\hline A-75-30-H & 850 & 65.63 & 59.06 & 66.50 & 13.11 & 3.22 \\
\hline A-75-50-F & 25 & 350.22 & 315.20 & - & 4.72 & 2.99 \\
\hline A-75-50-F & 550 & 275.54 & 247.99 & 21.32 & 5.61 & 3.20 \\
\hline A-75-50-F & 700 & 176.62 & 158.95 & 49.57 & 9.51 & 4.23 \\
\hline A-75-50-F & 850 & 95.42 & 85.87 & 72.76 & 13.41 & 5.72 \\
\hline A-75-50-H & 25 & 338.37 & 304.53 & - & 6.25 & 3.78 \\
\hline A-75-50-H & 550 & 263.67 & 237.30 & 22.08 & 9.26 & 4.79 \\
\hline A-75-50-H & 700 & 166.45 & 149.80 & 50.81 & 12.72 & 5.92 \\
\hline A-75-50-H & 850 & 81.81 & 73.63 & 75.82 & 21.51 & 3.86 \\
\hline A-75-80-F & 25 & 465.13 & 418.61 & - & 6.67 & 4.00 \\
\hline A-75-80-F & 550 & 431.48 & 388.33 & 7.23 & 9.75 & 5.99 \\
\hline A-75-80-F & 700 & 255.80 & 230.22 & 45.00 & 14.54 & 7.04 \\
\hline A-75-80-F & 850 & 187.41 & 168.67 & 59.71 & 18.65 & 6.30 \\
\hline A-75-80-H & 25 & 410.38 & 369.34 & - & 7.32 & 4.09 \\
\hline A-75-80-H & 550 & 375.36 & 337.83 & 8.53 & 10.38 & 5.72 \\
\hline A-75-80-H & 700 & 213.29 & 191.96 & 48.03 & 17.45 & 7.68 \\
\hline A-75-80-H & 850 & 158.55 & 142.69 & 61.37 & 18.20 & 5.42 \\
\hline
\end{tabular}

Table 6

Summary of failure loads and slips for all tested channel shear connector specimens in Group 2

\begin{tabular}{|c|c|c|c|c|c|c|}
\hline Specimen ID & 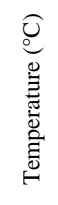 & 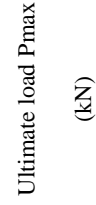 & 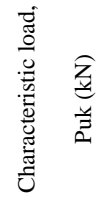 & 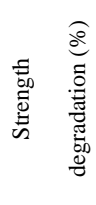 & 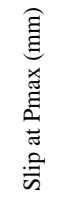 & 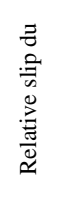 \\
\hline A-100-30-F & 25 & 279.58 & 251.62 & - & 6.44 & 3.67 \\
\hline A-100-30-F & 550 & 258.89 & 233.00 & 7.40 & 8.11 & 3.07 \\
\hline A-100-30-F & 700 & 163.21 & 146.89 & 41.62 & 13.33 & 6.80 \\
\hline A-100-30-F & 850 & 87.63 & 78.87 & 68.66 & 17.47 & 5.76 \\
\hline A-100-30-H & 25 & 226.54 & 203.88 & - & 7.85 & 5.01 \\
\hline A-100-30-H & 550 & 208.38 & 187.54 & 8.01 & 11.66 & 5.43 \\
\hline A-100-30-H & 700 & 141.51 & 127.36 & 37.53 & 16.92 & 6.65 \\
\hline A-100-30-H & 850 & 79.77 & 71.79 & 64.79 & 19.05 & 3.68 \\
\hline A-100-50-F & 25 & 439.48 & 395.53 & - & 7.33 & 4.42 \\
\hline A-100-50-F & 550 & 328.24 & 295.41 & 25.31 & 9.84 & 4.21 \\
\hline A-100-50-F & 700 & 270.84 & 243.75 & 38.37 & 12.00 & 4.50 \\
\hline A-100-50-F & 850 & 101.59 & 91.43 & 76.88 & 24.79 & 2.16 \\
\hline A-100-50-H & 25 & 380.76 & 342.68 & - & 8.25 & 4.16 \\
\hline A-100-50-H & 550 & 310.87 & 279.79 & 18.35 & 11.19 & 6.80 \\
\hline
\end{tabular}




\begin{tabular}{lcccccc} 
A-100-50-H & 700 & 226.28 & 203.65 & 40.57 & 18.54 & 7.00 \\
A-100-50-H & 850 & 95.36 & 85.82 & 74.96 & 22.71 & 1.86 \\
A-100-80-F & 25 & 596.39 & 536.75 & - & 8.48 & 5.41 \\
A-100-80-F & 550 & 521.35 & 469.22 & 12.58 & 11.40 & 9.73 \\
A-100-80-F & 700 & 277.10 & 249.39 & 53.54 & 16.82 & 6.51 \\
A-100-80-F & 850 & 119.16 & 107.24 & 80.02 & 22.62 & 6.72 \\
A-100-80-H & 25 & 587.25 & 528.53 & - & 10.77 & 5.02 \\
A-100-80-H & 550 & 490.19 & 441.17 & 16.53 & 12.64 & 7.45 \\
A-100-80-H & 700 & 332.77 & 299.49 & 43.34 & 18.44 & 5.69 \\
A-100-80-H & 850 & 115.75 & 104.17 & 80.29 & 20.72 & 5.20 \\
\hline
\end{tabular}

The load-slip curve for a single angle with stiffener was analysed to identify the stiffened angle shear connector's mechanical characteristics. Slip occurred under monotonic loading between the concrete block and the I-beam for all specimens at all temperatures. Consequently, sufficient ductility could be observed at all temperatures for the stiffened angle shear connectors, thereby satisfying the required ductility factor for shear connectors set by Eurocode 4) [43], which recommends that a connector can be regarded ductile under $6 \mathrm{~mm}$ slip capacity. This requirement was met for the samples at ambient temperatures. Samples at elevated temperatures satisfied this demand more easily than those at ambient temperatures because the elevated temperatures resulted in a large slip on the sample due to the mechanical properties exhibited by steel under high temperatures. Therefore, the samples at elevated temperatures were more ductile than those at ambient temperatures. An increase in temperature resulted in enhanced ductility and reduced strength because the strength of steel reduced at elevated temperature, making it substantially malleable and causing considerable ductile behaviour. In short, the stiffened angle shear connector with $75 \mathrm{~mm}$ height at ambient temperatures possessed a relative slip within the range of $4.72-7.32 \mathrm{~mm}$. At $550{ }^{\circ} \mathrm{C}, 700{ }^{\circ} \mathrm{C}$ and $850{ }^{\circ} \mathrm{C}$, the slips were $5.61-$ $10.38,9.51-7.45$ and $13.11-21.51 \mathrm{~mm}$, respectively. For the abovementioned shear connector with $100 \mathrm{~mm}$ height, at peak load, all specimens at ambient temperatures obtained a relative slip within the range of $6.49-10.77 \mathrm{~mm}$. Comparatively, the ranges of slip at temperatures of $550{ }^{\circ} \mathrm{C}, 700{ }^{\circ} \mathrm{C}$ and $850{ }^{\circ} \mathrm{C}$ were $8.11-12.64,12.00-18.54$ and $17.47-24.79 \mathrm{~mm}$, respectively. The majority of the samples showed a yield plateau from the load-slip curve, and the load capacity decreased rapidly and resulted in an abrupt completion of the load-slip curve because of the connectors' fracture. The yield plateau in the load-slip curve was observed at elevated temperature. This yield plateau was due to the effect of heating on steel, which showed that the shear connector reached the ultimate condition and the stiffener sustained the connector and illustrated the strength reduction in steel and great softening of steel at elevated temperatures. Consequently, with the increase in temperature, a decrease in connector strength was observed, which was between $6.82 \%$ and $75.82 \%$ in the stiffened angle shear connectors with $75 \mathrm{~mm}$ height and between $7.40 \%$ and $80.29 \%$ in those with $100 \mathrm{~mm}$ height at all temperatures. On the basis of the experimental data at high temperatures, the mentioned temperatures negatively affected the loadcarrying capacity of the connectors. In fact, elevated temperature in terms of time has an extraordinary destructive effect on the material properties, stability and failure of structure.

\subsection{Comparison of shear strength at ambient temperature}

The strength of shear connectors is one of their vital characteristics. This study has determined that, at ambient temperature, when the width was increased from $30 \mathrm{~mm}$ to 50 and $80 \mathrm{~mm}$, the strength was enhanced by an average of $66 \%$ and $126 \%$, respectively; when the shear connector's height was increased from $75 \mathrm{~mm}$ to $100 \mathrm{~mm}$, its strength was enhanced by approximately $26 \%$. Therefore, the width of a shear connector is more effective than its height similar to a nonstiffened shear connector. This research indicated that the stiffened angle shear connector at ambient temperature performed considerably better than the nonstiffened angle shear connector in the previous studies. Fig. 14a-h show a comparison of previous studies [8-11] of nonstiffened shear connectors embedded in normal and high-strength concrete with stiffened shear connectors; the minimum of strength enhancement was $93 \%$ and the maximum was $259 \%$, which confirmed the role of stiffeners with respect to the strength of shear connectors. Hence, the novelty of this work is that the designed stiffener enhances the strength significantly; the shape of the stiffener works as a truss to support the shear connector at ambient and elevated temperatures. This strength enhancement contributes significantly in terms of saving steel, cost and time, and stiffened shear connectors are considerably safer compared with nonstiffened shear connectors.

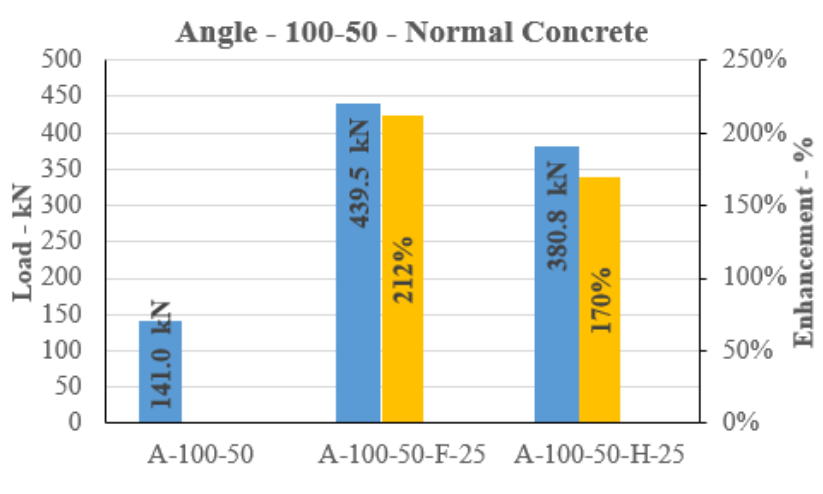

(a) 100-50 - Normal concrete

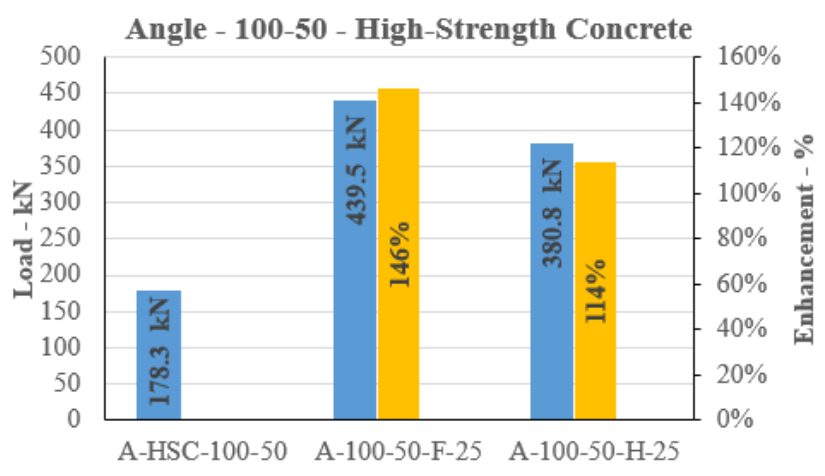

(b) 100-50 - High-Strength Concrete

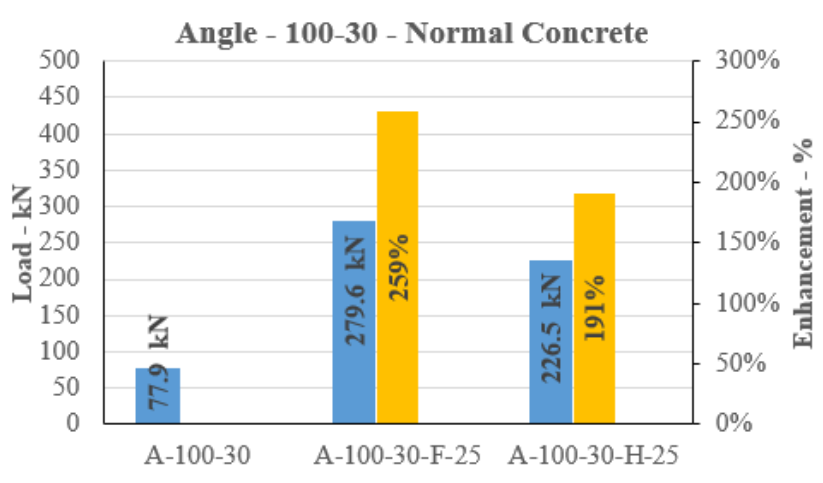

(c) 100-30 - Normal concrete

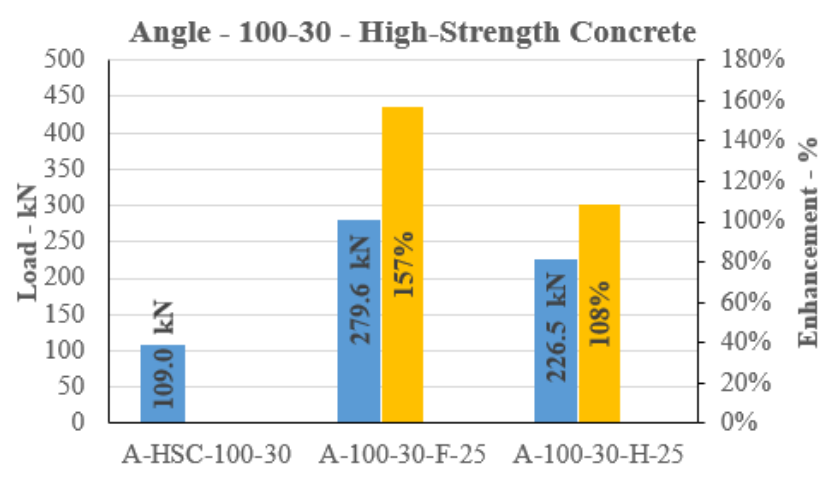

(d) 100-30 - High-Strength Concrete 


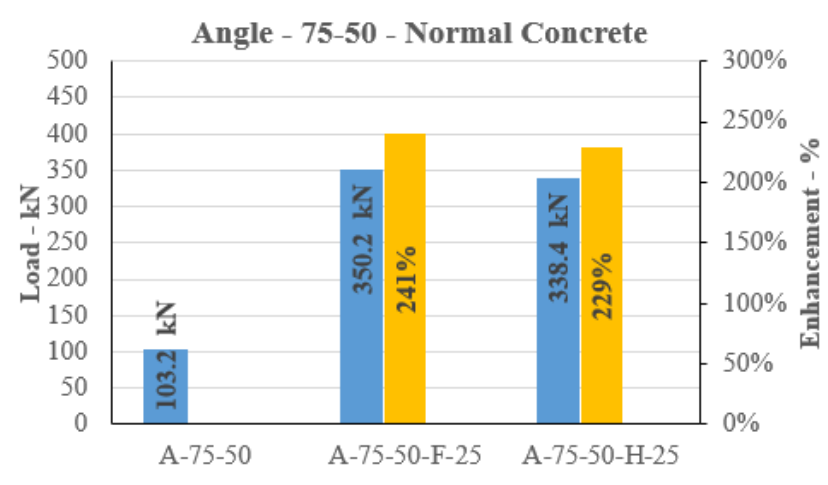

(e) 75-50 - Normal concrete

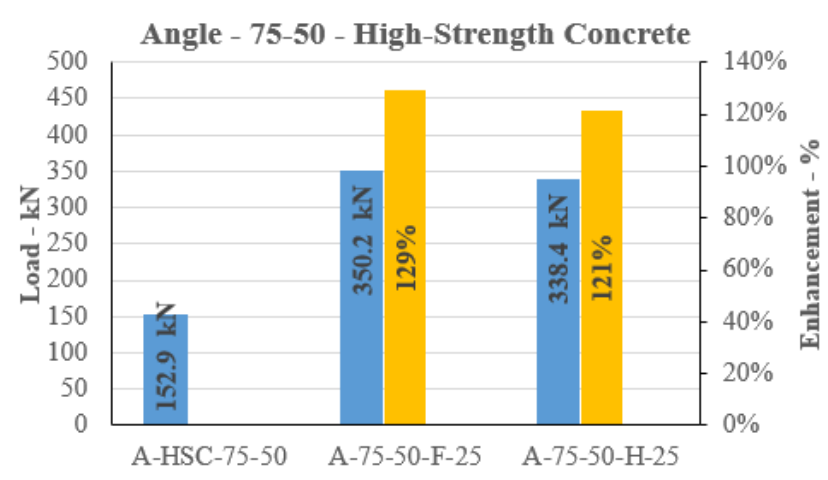

(f) 75-50 - High-Strength Concrete

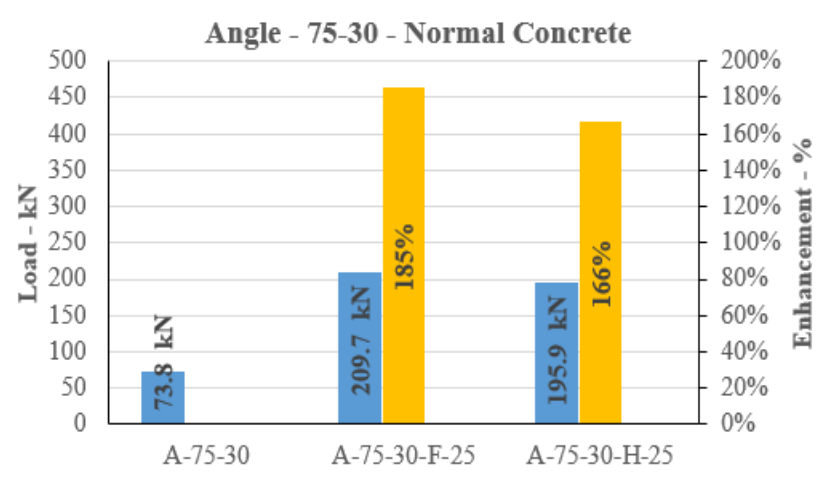

(g) 75-30 - Normal concrete

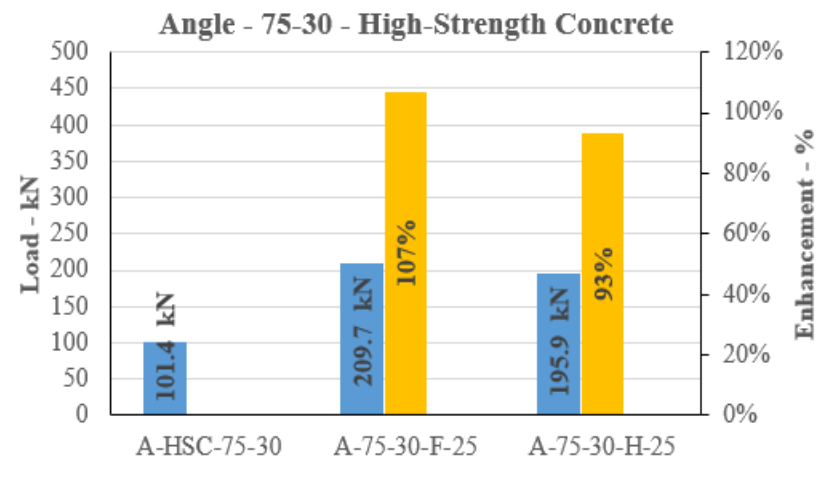

(h) 75-30 - High-Strength Concrete

Fig. 14 Strength enhancement of stiffened shear connectors compared with angle shear connectors embedded in normal- and high-strength concrete

\subsection{Shear strength reduction}

In accordance with Fig. 13, the load-slip curves are related to the monotonic load for all push-out samples at ambient and elevated temperatures. The final load and flexibility data in Tables 5 and 6 enable the shear durability decline for various shear connectors to be compared. High temperature adversely affected the resistance and stiffness of the angle shear connectors. Fig. 15 illustrates the influence of high temperature on the load-carrying capacity of the shear connectors in relation with the ones obtained at ambient temperatures. The ultimate load-carrying capacity of the angle shear connector decreased by approximately $6.82 \%-80.02 \%$ for the full-length stiffener and approximately $8.01 \%-80.20 \%$ for the half-length stiffener at different temperatures. Specifically, the strength reduction for the connector with $100 \mathrm{~mm}$ height was $68.60 \%-64.79 \%$ for $30 \mathrm{~mm}$ width, $76.68 \%-74.96 \%$ for $50 \mathrm{~mm}$ width and $80.02 \%-80.29 \%$ for $80 \mathrm{~mm}$ width. Likewise, the strength reduction for the 75 $\mathrm{mm}$ stiffened angle shear connector was $66.57 \%-66.50 \%$ for $30 \mathrm{~mm}$ width, $72.86 \%-75.82 \%$ for $50 \mathrm{~mm}$ width and $59.71 \%-61.37 \%$ for $80 \mathrm{~mm}$ width. Strength reduction at any temperature for the different shear connectors was nearly the same, which showed that the geometry and shape of the stiffened shear connectors had no effect on their strength. In addition, strength reduction depended strongly on temperature in terms of time due to specific heat. The specific heat of steel was enhanced by increasing the temperature. Accordingly, heating accelerated by increasing the temperature, which caused an acceleration in the strength reduction of steel. The trend of accelerating strength reduction could be determined by considering heating in terms of time, which was caused by the heat transfer coefficient. The reduction factors of the characteristic resistance (Pelevated/Pambient) for the stiffened angle shear connector decreased and converged with rising temperature (Figs. 15a and 15b). In consideration of the specimens, the standard deviations of the results were always less than 0.1 (Figs. 15a and 15b), illustrating the relation of full- and half-length stiffened angle shear connectors at elevated temperature; then the ambient temperatures approached each other for testing at different temperatures.

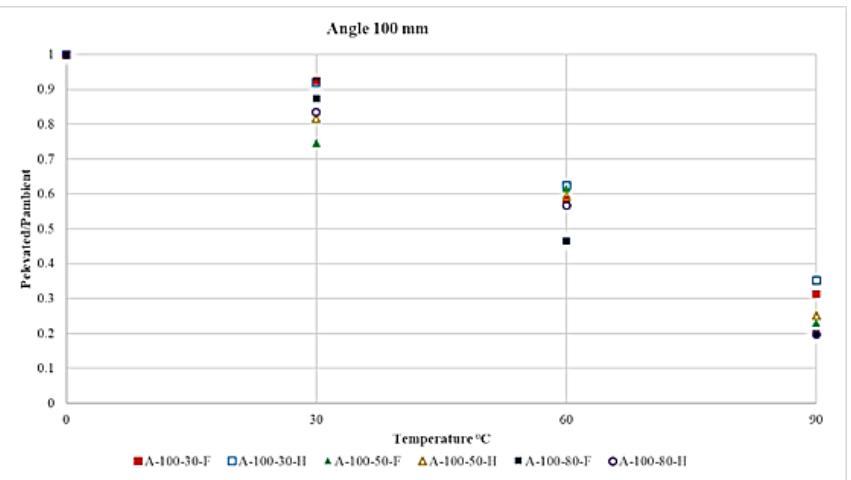

Fig. 15a Relative values of ultimate load-carrying capacity of $100 \mathrm{~mm}$ specimens

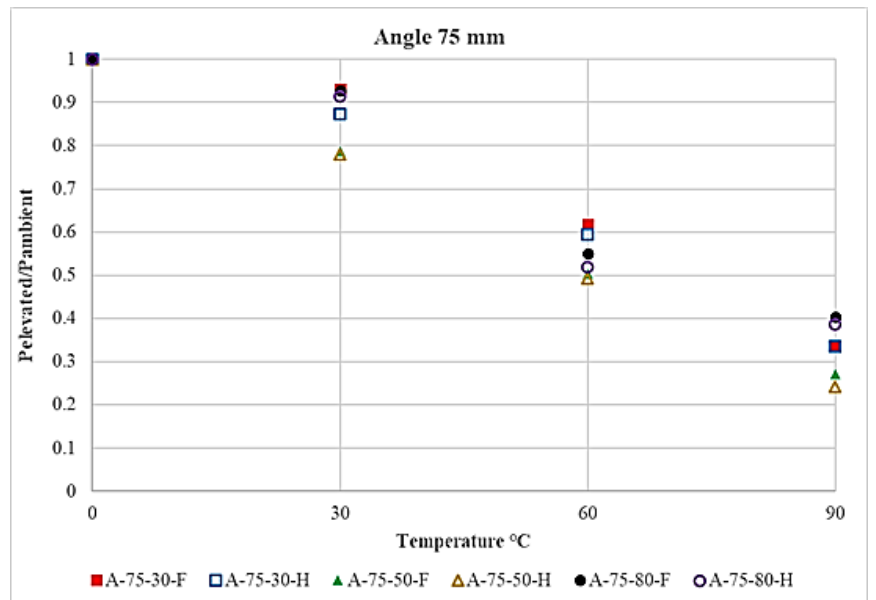

Fig. 15b Relative values of ultimate load-carrying capacity of $75 \mathrm{~mm}$ specimens

\subsection{Ductility factor}

A material's capacity to endure plastic deformation without breaking is called ductility. The load-slip curves allowed the evaluation of the shear connectors' flexibility factor $(\mu)$, thereby enabling an efficient comparison of the samples' flexibility. The ductility factor is a dimensionless quantity expressed as a ratio of ultimate deformation to yield deformation. With reference to the mentioned curve, flexibility may be assessed by applying a flexibility factor that is explained through an equivalent elastoplastic load deflection curve, as observed in Fig. 16. 


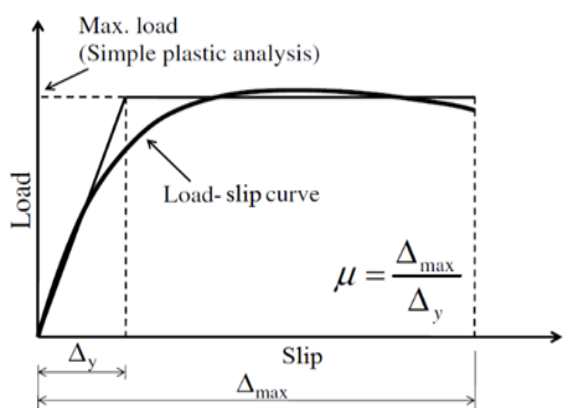

Fig. 16 Definition of ductility factor

The mentioned curve was idealised through two straight lines showing the original hardness and ultimate durability. These lines cross each other as the same yield dislocation $\Delta_{\mathrm{y}}$. The ultimate deflection, which is shown as $\Delta_{\max }$, is the deflection subjected to failure in the shear connector. The equivalent flexibility factor was measured as $\Delta_{\max } / \Delta_{\mathrm{y}}$. A high flexibility factor indicates a flexible composite system. In general, the direct relationship could be defined as follows: when the flexibility factor increases for a certain system, a decrease in the inelastic redistribution of the applied load is observed [27]. The results presented in Table 7 showed that the ductility of the shear connectors with 75 and $100 \mathrm{~mm}$ height improved by averages of $155 \%$ and $179 \%$, respectively, by elevating the temperature; however, the ductility of the stiffened angle shear connector with $100 \mathrm{~mm}$ height and $50 \mathrm{~mm}$ width (full- and half-length stiffeners) had the highest ductility amongst all the shear connectors and increased by $530 \%$. The geometry of the stiffened shear connector and temperature played a vital role with respect to the ductility of the shear connectors. The ductility of the shear connectors increased by decreasing the length of the connectors at ambient and elevated temperatures in most specimens. The shear connector with $80 \mathrm{~mm}$ width had lower ductility compared with the shear connector with 30 $\mathrm{mm}$ width. Despite the width of the shear connector, the length of the stiffener and the height of the shear connector played a vital role in the ductility factor. The ductility was enhanced by increasing the height of the shear connector, and the stiffened shear connectors with a half-length stiffener were more ductile than those with a full-length stiffener. With an increase in the width of the shear connectors, the stiffness increased, thereby reducing ductility. Ductility was considerably affected by temperature. Although increasing temperature reduced the strength of steel and concrete due to their properties, it enhanced ductility. The load-slip curves in Fig. 10 indicate that, at ambient temperatures, the shear connector with $80 \mathrm{~mm}$ width bore the highest load compared with those with 30 and $50 \mathrm{~mm}$ width; nevertheless, the ductility at this temperature was nearly in a stable range. When the temperature was increased to $550{ }^{\circ} \mathrm{C}$, the shear connector with $80 \mathrm{~mm}$ width had the highest carrying load, and the shear connector with $30 \mathrm{~mm}$ width became increasingly ductile. At $700{ }^{\circ} \mathrm{C}$, the shear connectors exhibited the same behaviour as that at $550{ }^{\circ} \mathrm{C}$. At $850{ }^{\circ} \mathrm{C}$, the shear connector with $80 \mathrm{~mm}$ width still obtained the highest load, whereas the shear connector with $50 \mathrm{~mm}$ width demonstrated more ductility. In summary, the shear connector with $80 \mathrm{~mm}$ width could carry more load. The shear connector with $100 \mathrm{~mm}$ height was more ductile than that with $75 \mathrm{~mm}$ height due to the use of a stiffener. In addition, using a half-length stiffener facilitated the enhancement of ductility more than adopting a full-length stiffener. The results generally showed that the ductility of a stiffened angle shear connector increased by raising the temperature, as illustrated in Fig. 17a-b.

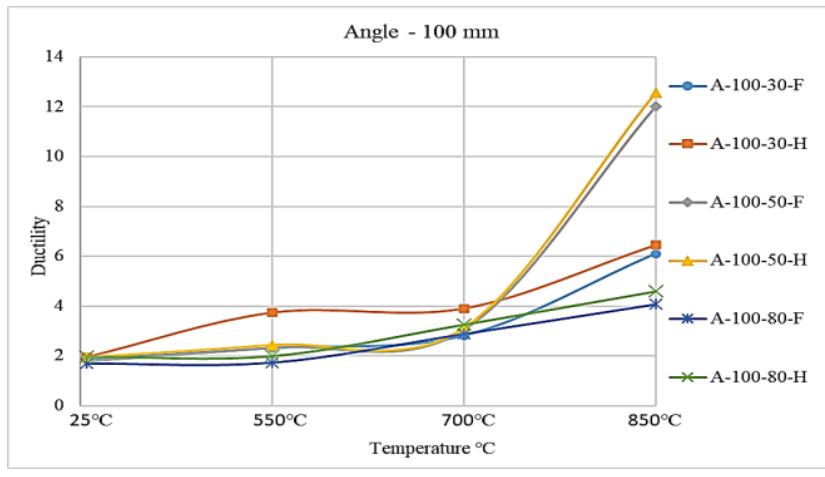

(a) Stiffened angle $-100 \mathrm{~mm}$ heigth

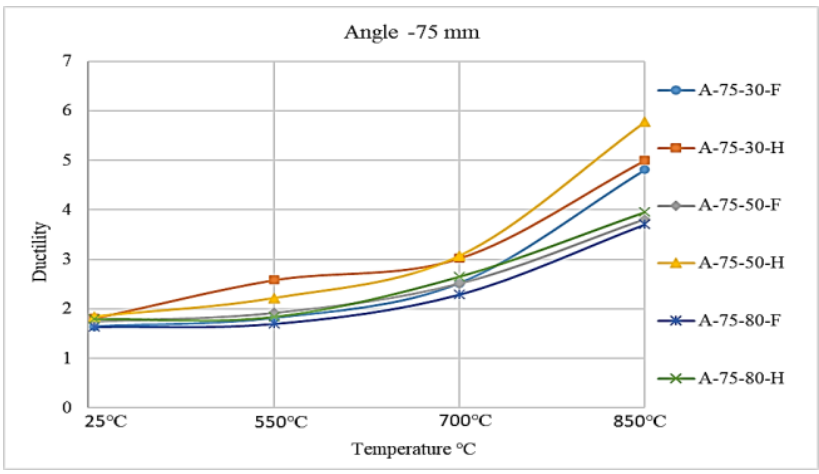

(b) Stiffened angle $-75 \mathrm{~mm}$ heigth

Fig. 17 Ductility-temperature graphs of stiffened angle shear connectors

Table 7

Ductility factor for each specimen of angle shear connector

\begin{tabular}{|c|c|c|c|c|c|}
\hline & Specimen ID & Temperature & max slip & $\Delta \mathrm{y}$ & $\mu$ \\
\hline 1 & A-100-30-F & 25 & 6.4 & 3.16 & 2.04 \\
\hline 2 & A-100-30-F & 550 & 8.1 & 2.9 & 2.80 \\
\hline 3 & A-100-30-F & 700 & 13.3 & 4.59 & 2.90 \\
\hline 4 & A-100-30-F & 850 & 17.5 & 2.79 & 6.26 \\
\hline 5 & A-100-30-H & 25 & 7.9 & 4 & 1.96 \\
\hline 6 & A-100-30-H & 550 & 11.7 & 3 & 3.89 \\
\hline 7 & A-100-30-H & 700 & 16.9 & 4 & 4.23 \\
\hline 8 & A-100-30-H & 850 & 19.1 & 2.7 & 7.06 \\
\hline 9 & A-100-50-F & 25 & 7.3 & 4.1 & 1.79 \\
\hline 10 & A-100-50-F & 550 & 9.8 & 3.5 & 2.81 \\
\hline 11 & A-100-50-F & 700 & 12.0 & 3.6 & 3.33 \\
\hline 12 & A-100-50-F & 850 & 24.8 & 2 & 12.40 \\
\hline 13 & A-100-50-H & 25 & 8.3 & 3.7 & 2.23 \\
\hline 14 & A-100-50-H & 550 & 11.2 & 4.3 & 2.60 \\
\hline 15 & A-100-50-H & 700 & 18.5 & 5.8 & 3.20 \\
\hline 16 & A-100-50-H & 850 & 22.7 & 1.8 & 12.62 \\
\hline 17 & A-100-80-F & 25 & 8.5 & 4.7 & 1.80 \\
\hline 18 & A-100-80-F & 550 & 11.4 & 6.2 & 1.84 \\
\hline 19 & A-100-80-F & 700 & 16.8 & 5.6 & 3.00 \\
\hline 20 & A-100-80-F & 850 & 22.6 & 5.2 & 4.35 \\
\hline 21 & A-100-80-H & 25 & 10.8 & 4.8 & 2.24 \\
\hline 22 & A-100-80-H & 550 & 12.6 & 6.2 & 2.04 \\
\hline 23 & A-100-80-H & 700 & 18.4 & 5.4 & 3.42 \\
\hline 24 & A-100-80-H & 850 & 20.7 & 4.4 & 4.71 \\
\hline 25 & A-75-30-F & 25 & 4.9 & 2.8 & 1.75 \\
\hline 26 & A-75-30-F & 550 & 9.1 & 4.63 & 1.96 \\
\hline 27 & A-75-30-F & 700 & 13.3 & 5 & 2.66 \\
\hline 28 & A-75-30-F & 850 & 16.6 & 3.2 & 5.18 \\
\hline 29 & A-75-30-H & 25 & 5.9 & 3.2 & 1.84 \\
\hline 30 & A-75-30-H & 550 & 7.6 & 2.9 & 2.63 \\
\hline 31 & A-75-30-H & 700 & 12.5 & 4 & 3.13 \\
\hline 32 & A-75-30-H & 850 & 13.1 & 2.6 & 5.04 \\
\hline 33 & A-75-50-F & 25 & 4.7 & 2.6 & 1.82 \\
\hline 34 & A-75-50-F & 550 & 5.6 & 2.65 & 2.12 \\
\hline 35 & A-75-50-F & 700 & 9.5 & 3.7 & 2.57 \\
\hline 36 & A-75-50-F & 850 & 13.4 & 3.5 & 3.83 \\
\hline 37 & A-75-50-H & 25 & 6.2 & 3.3 & 1.89 \\
\hline
\end{tabular}




\begin{tabular}{llllll}
38 & A-75-50-H & 550 & 9.3 & 4.1 & 2.26 \\
39 & A-75-50-H & 700 & 12.7 & 4.1 & 3.10 \\
40 & A-75-50-H & 850 & 21.5 & 3.6 & 5.98 \\
41 & A-75-80-F & 25 & 6.7 & 3.7 & 1.80 \\
42 & A-75-80-F & 550 & 9.7 & 5.6 & 1.74 \\
43 & A-75-80-F & 700 & 14.5 & 6.2 & 2.35 \\
44 & A-75-80-F & 850 & 18.7 & 4.8 & 3.89 \\
45 & A-75-80-H & 25 & 7.3 & 4 & 1.83 \\
46 & A-75-80-H & 550 & 10.4 & 5.2 & 2.00 \\
47 & A-75-80-H & 700 & 17.5 & 6.4 & 2.73 \\
48 & A-75-80-H & 850 & 18.2 & 4.6 & 3.96 \\
\hline
\end{tabular}

\section{Conclusions}

In this study, stiffened angle shear connectors were proposed and tested in a push-out test. The samples' temperatures were initially increased from room temperature to $550{ }^{\circ} \mathrm{C}, 700{ }^{\circ} \mathrm{C}$ and $850{ }^{\circ} \mathrm{C}$, and they were successively loaded to failure to evaluate their resistance and relative flexibility at high temperatures. In most push-out samples at room or target temperature, a connector fracture was observed. In consideration of the load-slip curves for all samples, at the ultimate load, the relative slip of the stiffened angle shear connectors was within the range of $4.72-10.77 \mathrm{~mm}$ at room temperature. The mentioned ranges for all samples at $550^{\circ} \mathrm{C}, 700{ }^{\circ} \mathrm{C}$ and $850^{\circ} \mathrm{C}$ were $5.61-12.64,9.51-18.54$ and $13.11-$ $24.79 \mathrm{~mm}$, respectively. In conclusion, shear durability decreases of $155 \%$ and $179 \%$ for various stiffened angle shear connectors with 75 and $100 \mathrm{~mm}$ height, respectively, were observed. On the basis of the obtained data, a relationship was found between flexibility and temperature. As the test temperatures increased, the connectors' flexibility increased due to the properties of steel at elevated temperatures. In general, at elevated temperatures, more flexibility was observed for long connectors compared with that for short connectors. The results of this research showed that temperature had a destructive effect on the properties of concrete and steel and affected the load capacity of the shear connectors. The load capacity of the mentioned connectors at elevated temperatures was considerably lower than at ambient temperatures. Moreover, the shear strength was reduced by decreasing the load capacity. Strength reductions of $6.82 \%-80.02 \%$ and $8.01 \% 80.20 \%$ were observed for full- and half-length stiffeners, respectively. These results illustrated that the ductility of connectors increased by increasing the temperature. Given that the strength and mechanical properties of steel and concrete decrease significantly at elevated temperature, a specific design is required to address the mentioned drawback. Hence, the novelty of this work in designing a stiffener for angle shear connectors clearly has a vital role in enhancing the resistance of shear connectors at elevated temperature.

\section{Acknowledgements}

The authors would like to acknowledge the support of University of Malaya UMRG (University of Malaya Research Grant), Project Number: RP004C13AET and IPPP Grant, Project Number: PG084-2016A.

\section{References}

[1] Viest, I.M., et al., Composite construction design for buildings. 1997: McGraw-Hill New York.

[2] Viest, I. Investigation of stud shear connectors for composite concrete and steel T-beams. in Journal Proceedings. 1956.

[3] Hegger, J., S. Rauscher, and C. Goralski, Push-out tests on headed studs in high-strength concrete. Special Publication, 2005. 228: p. 769-786.

[4] Manual, S.C., American institute of steel construction. Inc., Thirteenth Edition, First Print, 2005.

[5] Slutter, R.G. and G.C. Driscoll Jr, Flexural strength of steel and concrete composite beams. 1963.

[6] Hawkins, N.M. and D. Mitchell, Seismic response of composite shear connections. Journal of Structural Engineering, 1984. 110(9): p. 2120-2136

[7] Tahmasbi, F., et al., Shear capacity of C-shaped and L-shaped angle shear connectors. PloS one, 2016. 11(8): p. e0156989.

[8] Shariati, M., N.R. Sulong, and M.A. Khanouki, Experimental assessment of channel shear connectors under monotonic and fully reversed cyclic loading in high strength concrete. Materials \& Design, 2012. 34: p. 325-331.

[9] Shariati, M., et al., Comparison of behaviour between channel and angle shear connectors under monotonic and fully reversed cyclic loading. Construction and Building Materials, 2013. 38: p. 582-593.

[10] Shariati, M., et al., Behaviour of C-shaped angle shear connectors under monotonic and fully reversed cyclic loading: An experimental study. Materials \& Design, 2012. 41: p. 67-73.

[11] Shariati, M., et al., Fatigue energy dissipation and failure analysis of angle shear connectors embedded in high strength concrete. Engineering Failure Analysis, 2014. 41: p. 124-134.
[12] Maleki, S. and S. Bagheri, Behavior of channel shear connectors, Part I: Experimental study. Journal of Constructional Steel Research, 2008. 64(12): p. 1333-1340.

[13] Maleki, S. and S. Bagheri, Behavior of channel shear connectors, Part II: Analytical study. Journal of Constructional Steel Research, 2008. 64(12): p. 1341-1348.

[14] Maleki, S. and M. Mahoutian, Experimental and analytical study on channel shear connectors in fiber-reinforced concrete. Journal of Constructional Steel Research, 2009. 65(8-9): p. 1787-1793.

[15] O'Connor, M. and D. Martin, Behaviour of a multi-storey steel framed building subjected to fire attack. Journal of Constructional Steel Research, 1998. 1(46): p. 295.

[16] Sanad, A., et al., Composite beams in large buildings under fire-numerical modelling and structural behaviour. Fire Safety Journal, 2000. 35(3): p. 165-188.

[17] Mäkeläinen, P. and Z. Ma, Fire resistance of composite slim floor beams. Journal of constructional steel research, 2000. 54(3): p. 345-363.

[18] Mirza, O. and B. Uy, Behaviour of headed stud shear connectors for composite steel-concrete beams at elevated temperatures. Journal of Constructional Steel Research, 2009. 65(3): p. 662-674.

[19] Rodrigues, J.P.C. and L. Laím, Experimental investigation on the structural response of T, Tblock and T-Perfobond shear connectors at elevated temperatures. Engineering structures, 2014. 75: p. 299-314

[20] Rodrigues, J.P.C. and L. Laím, Behaviour of perfobond shear connectors at high temperatures. Engineering Structures, 2011. 33(10): p. 2744-2753.

[21] Fuh-Gwo, Y. and R.E. Miller, A new finite element for laminated composite beams. Computers \& structures, 1989. 31(5): p. 737-745.

[22] Shariati, M., et al. Experimental and analytical study on channel shear connectors in light weight aggregate concrete. in Proceedings of the 4th international conference on steel \& composite structures. 2010.

[23] Shariati, M., et al. Behavior of channel shear connectors in normal and light weight aggregate concrete (experimental and analytical study). in Advanced Materials Research. 2011. Trans Tech Publ.

[24] Shariati, A., et al., Investigation of channel shear connectors for composite concrete and steel T-beam. International journal of physical sciences, 2012. 7(11): p. 1828-1831.

[25] Shariati, A., N. RamliSulong, and M. Shariati, Various types of shear connectors in composite structures: A review. International journal of physical sciences, 2012. 7(22): p. 2876-2890.

[26] Shariati, M., et al. Fatigue energy dissipation and failure analysis of channel shear connector embedded in the lightweight aggregate concrete in composite bridge girders. in Fifth international conference on engineering failure analysis. 2012.

[27] Baran, E. and C. Topkaya, An experimental study on channel type shear connectors. Journal of Constructional Steel Research, 2012. 74: p. 108-117.

[28] ASTM, A., 370, "Standard Test Methods and Definitions for Mechanical Testing of Steel Products". Anual Book of Standard, 2005.

[29] Sajedi, F. and H.A. Razak, The effect of chemical activators on early strength of ordinary Portland cement-slag mortars. Construction and Building Materials, 2010. 24(10): p. 19441951.

[30] Neville, A., Properties of concrete. Malaysia: Prentice Hall. 2008.

[31] Razak, H.A. and F. Sajedi, The effect of heat treatment on the compressive strength of cement-slag mortars. Materials \& Design, 2011. 32(8-9): p. 4618-4628.

[32] ASTM, C., Standard test method for compressive strength of cylindrical concrete specimens. 2012.

[33] Neville, A. and J. Brooks, Concrete technology. Malaysia: Prentice Hall. 2008.

[34] Sajedi, F., Mechanical activation of cement-slag mortars. Construction and Building Materials, 2011. doi:10.1016/j.conbuildmat.2011.05.001.

[35] ASTM, C., 39 (2004)"Standard test method for compressive strength of cylindrical concrete specimens.". Annual Book of ASTM Standards, 2005.

[36] Haremza, C., A. Santiago, and L.S. da Silva, Experimental behaviour of heated composite steel-concrete joints subject to variable bending moments and axial forces. Engineering Structures, 2013. 51: p. 150-165.

[37] Maleki, S. and S. Bagheri, Behavior of channel shear connectors, Part II: Analytical study. Journal of Constructional Steel Research, 2008. 64 p. 1341-1348.

[38] Maleki, S. and S. Bagheri, Behavior of channel shear connectors, Part I: Experimental study. Journal of Constructional Steel Research, 2008. 64 p. 1333-1340.

[39] Tests, I., Elements of Building Construction, ISO-834. International Organization for Standardization. Geneva, 1975.

[40] Harmathy, T., Thermal properties of concrete at elevated temperatures. Journal of Materials, 1970.

[41] Bazant, Z.P. and M.F. Kaplan, Concrete at high temperature. Material Properties and Mathematical ModelsLongman Group Limited, Essex, England, 1996.

[42] CSN, E., 1-2: Eurocode 2: Design of Concrete Structures-Part 1-2: General Rules-Structural Fire Design. 2006, CNI, Praha.

[43] Eurocode, E., 4: Design of composite steel and concrete structures-Part 1-2: General rulesStructural fire design. British Standards Institution, BS EN, 1994: p. 1-2. 